\title{
The Progressive Ankylosis Protein Regulates Cementum Apposition and Extracellular Matrix Composition
}

\author{
B.L. Foster ${ }^{a}$ b K.J. Nagatomo ${ }^{a}$ S.O. Bamashmous ${ }^{a, b}$ K.A. Tompkins ${ }^{a, e}$ \\ H. Fong ${ }^{c}$ D. Dunn ${ }^{a}$ E.Y. Chu ${ }^{a, b} \quad$ C. Guenther ${ }^{d}$ D.M. Kingsley ${ }^{d}$
}

R.B. Rutherford ${ }^{b}$ M.J. Somerman ${ }^{a, b}$

Departments of a Periodontics and ${ }^{\mathrm{b}}$ Oral Biology, University of Washington School of Dentistry, and ${ }^{\mathrm{C}}$ Department of Material Science and Engineering, University of Washington, Seattle, Wash., and ${ }^{\mathrm{d}}$ Department of Developmental Biology, HHMI and Stanford University, Stanford, Calif.; ${ }^{~}$ Departments of Oral Biology and Implantology, Faculty of Dentistry, Chulalongkorn University, Bangkok, Thailand

\section{Key Words}

Cementum • Progressive ankylosis protein • ANK •

Pyrophosphate $\cdot$ Periodontal ligament

\begin{abstract}
Background/Aims: Tooth root cementum is sensitive to modulation of inorganic pyrophosphate $\left(\mathrm{PP}_{\mathrm{i}}\right)$, an inhibitor of hydroxyapatite precipitation. Factors increasing $\mathrm{PP}_{\mathrm{i}}$ include progressive ankylosis protein (ANK) and ectonucleotide pyrophosphatase/phosphodiesterase 1 (NPP1) while tissue nonspecific alkaline phosphatase hydrolyzes $\mathrm{PP}_{\mathrm{i}}$. Studies here aimed to define the role of ANK in root and cementum by analyzing tooth development in Ank knock-out (KO) mice versus wild type. Materials and Methods: Periodontal development in $\mathrm{KO}$ versus control mice was analyzed by histology, histomorphometry, immunohistochemistry, in situ hybridization, electron microscopy, and nanoindentation. Cementoblast cultures were used in vitro to provide mechanistic underpinnings for $\mathrm{PP}_{\mathrm{i}}$ modulation of cell function. $\boldsymbol{R e}$ sults: Over the course of root development, Ank KO cervical
\end{abstract}

cementum became 8- to 12 -fold thicker than control cervical cementum. Periodontal ligament width was maintained and other dentoalveolar tissues, including apical cementum, were unaltered. Cervical cementum uncharacteristically included numerous cells, from rapid cementogenesis. Ank KO increased osteopontin and dentin matrix protein 1 gene and protein expression, and markedly increased NPP1 protein expression in cementoblasts but not in other cell types. Conditional ablation of Ank in joints and periodontia confirmed a local role for ANK in cementogenesis. In vitro studies employing cementoblasts indicated that Ank and Enpp1 mRNA levels increased in step with mineral nodule formation, supporting a role for these factors in regulation of cementum matrix mineralization. Conclusion: ANK, by modulating local $\mathrm{PP}_{\mathrm{i}}$, controls cervical cementum apposition and extracellular matrix. Loss of ANK created a local environment conducive to rapid cementogenesis; therefore, approaches modulating $\mathrm{PP}_{\mathrm{i}}$ in periodontal tissues have potential to promote cementum regeneration.

\section{KARGER}

Fax +4161306 1234

E-Mail karger@karger.ch

www.karger.com (c) 2011 S. Karger AG, Basel

Accessible online at: www.karger.com/cto
Mr. Brian L. Foster

Department of Periodontics, University of Washington School of Dentistry 1959 NE Pacific St., Box 357444

Seattle, WA 98195 (USA)

Tel. +1 206685 2129, E-Mail blfoster@u.washington.edu 


\begin{tabular}{|c|c|}
\hline \multicolumn{2}{|c|}{ Abbreviations used in this paper } \\
\hline AA & ascorbic acid \\
\hline $\mathrm{ABC}$ & alveolar bone crest \\
\hline AEFC & acellular extrinsic fiber cementum \\
\hline$A k p 2$ & tissue nonspecific alkaline phosphatase gene \\
\hline ANK & progressive ankylosis gene/protein \\
\hline ANKH & progressive ankylosis gene/protein, human homologue \\
\hline Ank KO & progressive ankylosis knock-out mouse \\
\hline ANOVA & analysis of variance \\
\hline BGP & $\beta$-glycerophosphate \\
\hline BSE & backscatter mode \\
\hline BSP & bone sialoprotein gene/protein \\
\hline CEJ & cementum-enamel junction \\
\hline CMD & craniometaphyseal dysplasia \\
\hline cRNA & complementary ribonucleic acid \\
\hline DIG & digoxigenin \\
\hline DMEM & Dulbecco's modified Eagle medium \\
\hline DMP1 & dentin matrix protein 1 gene/protein \\
\hline $\mathrm{dpc}$ & days post coitum \\
\hline Dspp & dentin sialophosphoprotein gene \\
\hline Enpp1 & ectonucleotide pyrophosphatase phosphodiesterase 1 gene \\
\hline FBS & fetal bovine serum \\
\hline Gapdh & glyceraldehyde 3-phosphate dehydrogenase gene \\
\hline Gdf5 & growth/differentiation factor 5 gene \\
\hline HAP & hydroxyapatite \\
\hline $\mathrm{HE}$ & hematoxylin and eosin \\
\hline IHC & immunohistochemistry \\
\hline ISH & in situ hybridization \\
\hline MEPE & matrix extracellular phosphoglycoprotein \\
\hline mRNA & messenger ribonucleic acid \\
\hline NIDCR & National Institute of Dental and Craniofacial Research \\
\hline $\mathrm{NIH}$ & National Institutes of Health \\
\hline NPP1 & ectonucleotide pyrophosphatase phosphodiesterase 1 protein \\
\hline OCN & osteocalcin gene/protein \\
\hline OPN & osteopontin gene/protein \\
\hline PBS & phosphate-buffered saline \\
\hline PDL & periodontal ligament \\
\hline$P_{i}$ & inorganic phosphate; orthophosphate \\
\hline $\mathrm{PP}_{\mathrm{i}}$ & inorganic pyrophosphate \\
\hline qRT-PCR & $\begin{array}{l}\text { real-time quantitative reverse transcription polymerase chain } \\
\text { reaction }\end{array}$ \\
\hline RT-PCR & reverse transcription polymerase chain reaction \\
\hline SEM & scanning electron microscopy \\
\hline SIBLING & small integrin-binding ligand, $\mathrm{N}$-linked glycoprotein \\
\hline TAg & $\mathrm{T}$ antigen \\
\hline TNAP & tissue nonspecific alkaline phosphatase protein \\
\hline TRAP & tartrate resistant acid phosphatase \\
\hline tRNA & transfer ribonucleic acid \\
\hline$t t w$ & tiptoe walking \\
\hline UTP & uridine triphosphate \\
\hline WT & wild type \\
\hline
\end{tabular}

\section{Introduction}

Inorganic phosphate $\left(\mathrm{P}_{\mathrm{i}}, \mathrm{PO}_{4}{ }^{3-}\right)$ homeostasis is essential for normal development, maintenance, and repair of teeth and skeletal tissues [Foster et al., 2008, and references therein]. Most $\mathrm{P}_{\mathrm{i}}$ in the body is found in bones and teeth, compounded with ionic calcium as hydroxyapatite
(HAP). Pyrophosphate $\left(\mathrm{PP}_{\mathrm{i}}, \mathrm{P}_{2} \mathrm{O}_{7}^{4-}\right)$ is present in numerous bodily fluids, at the cell and tissue levels, and in mineralized matrices of bones and teeth [Heinonen, 2001, and references therein]. In vitro and in vivo data have established $\mathrm{PP}_{\mathrm{i}}$ as a potent inhibitor of HAP crystal growth via binding to crystal surfaces to prevent further crystal growth [Fleisch and Bisaz, 1962; Meyer, 1984]. Alterations in $\mathrm{P}_{\mathrm{i}}$ and $\mathrm{PP}_{\mathrm{i}}$ levels are of central importance for both proper formation of mineralized tissues and prevention of pathological calcifications [Koshizuka et al., 2001; Terkeltaub, 2001; Murshed et al., 2005; Lomashvili et al., 2008]. Hydrolysis of $\mathrm{PP}_{\mathrm{i}}$ to liberate $\mathrm{P}_{\mathrm{i}}$ provides a physiological link between the inhibitor of HAP (i.e. $\mathrm{PP}_{\mathrm{i}}$ ) and one of its components (i.e. $\mathrm{P}_{\mathrm{i}}$ ); it is an exquisite system of feedback and regulation.

Cementum is the thin mineralized tissue covering the tooth root as part of the periodontal attachment complex [Diekwisch, 2001; Bosshardt, 2005; Foster et al., 2007]. Cementum is critical for tooth attachment by anchoring the tooth proper to the surrounding alveolar bone via the unmineralized periodontal ligament (PDL) [Beertsen et al., 1997; Shimono et al., 2003]. The initial cementum produced on the cervical portion of the root is the acellular cementum (acellular extrinsic fiber cementum, AEFC). Toward the apex of the mature tooth, cementum is produced as a thicker, cellular tissue as cementoblasts become entrapped within the cementum matrix (cellular intrinsic fiber cementum or cellular mixed stratified cementum).

Cementum is sensitive to $\mathrm{P}_{\mathrm{i}}$ and $\mathrm{PP}_{\mathrm{i}}$ homeostasis, as demonstrated by observations in both mouse models and human patients. Local pericellular concentrations of $\mathrm{PP}_{\mathrm{i}}$ are controlled primarily by a number of regulatory enzymes and transporters. Tissue nonspecific alkaline phosphatase (TNAP), an ectoenzyme which can hydrolyze $\mathrm{PP}_{\mathrm{i}}$, is expressed by bone and is present at high levels in the periodontia [Groeneveld et al., 1995, 1996]. Hypophosphatasia, which causes poor bone mineralization, rickets and osteomalacia, results from mutations in the gene for TNAP ( $A l p l$ or $A k p 2$, GeneID 249 in humans; GeneID 11647 in the mouse) [Whyte, 1994; Narisawa et al., 1997; Whyte, 2002; Millan, 2006]. Hypophosphatasia provided the first linkage of $\mathrm{PP}_{\mathrm{i}}$ homeostasis with a cementum phenotype [Whyte, 1994; van den Bos et al., 2005]. In both humans and mice, TNAP deficiency causes cementum aplasia or severe hypoplasia, poor attachment and exfoliation of teeth [Beertsen et al., 1999; van den Bos et al., 2005].

The progressive ankylosis gene (ANKH in humans, GeneID 56172; Ank in the mouse, GeneID 11732) encodes 
a transmembrane protein regulating transport of intracellular $\mathrm{PP}_{\mathrm{i}}$ to the extracellular space [Ho et al., 2000; Johnson et al., 2003; Gurley et al., 2006b]. Therefore, ANK offsets TNAP activity by increasing extracellular $\mathrm{PP}_{\mathrm{i}}$. Loss of ANK function results in decreased extracellular $\mathrm{PP}_{\mathrm{i}}$, and mice lacking ANK exhibit an arthritis-like phenotype characterized by ectopic calcifications in cartilage and joint tissues [Ho et al., 2000; Terkeltaub, 2001; Harmey et al., 2004; Gurley et al., 2006a]. In humans, ANKH mutations are linked to both craniometaphyseal dysplasia (CMD), characterized by overgrowth and sclerosis of craniofacial bones and abnormal modeling of long-bone metaphyses [Nurnberg et al., 2001; Reichenberger et al., 2001], and chondrocalcinosis, resulting from deposition of calcium pyrophosphate dihydrate within articular cartilage [Ryan, 2001; Pendleton et al., 2002; Netter et al., 2004; Gurley et al., 2006b]. Our group described the intriguing tooth phenotype in classical Ank mutant mice, characterized by a marked increase in cementum formation, while other tooth tissues (e.g. PDL, dentin and alveolar bone) appeared to be unaffected [Nociti et al., 2002; Fong et al., 2009]. Another $\mathrm{PP}_{\mathrm{i}}$ regulator, ectonucleotide pyrophosphatase phosphodiesterase 1 (NPP1; Enpp1 or PC-1, GeneID 5167 in humans; GeneID 18605 in the mouse) also works to increase extracellular $\mathrm{PP}_{\mathrm{i}}$, and mice lacking NPP1 function feature a joint phenotype resembling that seen with ANK deficiency [Johnson et al., 2000; Terkeltaub, 2001; Hessle et al., 2002; Johnson et al., 2003]. The tooth phenotype of Enpp1 mutant mice (also known as tiptoe walking, $t t w$ ) was demonstrated to be similar to the hypercementosis found in Ank mutant mice [Nociti et al., 2002].

$\mathrm{PP}_{\mathrm{i}}$ regulating factors such as ANK clearly function in tooth root development as demonstrated by root phenotypes; however, the mechanism(s) responsible are not well understood. Studies here aimed to further define the role of ANK in tooth root and cementum formation by analyzing tooth development in Ank knock-out (KO) mice versus wild type (WT). As controversy exists on how ANK function was altered in classical Ank mutant mice, we employed the Ank KO mouse model as an unequivocal model for loss of ANK function and decreased $\mathrm{PP}_{\mathrm{i}}$, and further used a conditional Ank KO to confirm hypotheses on local ANK regulation. In vivo observations were further tested using in vitro cell culture experiments. We hypothesized, based on previous characterizations, that ANK may be differentially expressed in the cementumPDL region versus other tissues, providing an explanation for the seemingly greater sensitivity of cementum to $\mathrm{PP}_{\mathrm{i}}$ perturbation compared to dentin, enamel and alveo- lar bone. Further, based on in vitro and in vivo evidence for $\mathrm{P}_{\mathrm{i}}$ and $\mathrm{PP}_{\mathrm{i}}$ regulation of cementogenesis [Foster et al., 2005, 2006; Rutherford et al., 2006; Foster et al., 2008], we hypothesized that dysregulation of $\mathrm{PP}_{\mathrm{i}}$ resulting from Ank KO would result in increased cementum apposition in association with altered cementoblast expression of mineralization-related genes and proteins.

\section{Materials and Methods}

\section{Animals}

Preparation and genotyping of Ank KO, AnkfloxP, and Gdf5Cre mice were described previously [Gurley et al., 2006a]. Heterozygote breeding pairs were employed to prepare homozygote Ank KO mice and age-matched WT controls at specific ages during tooth development from 24 to 79 days post coitum (dpc), where birth usually falls on $19 \mathrm{dpc}$. In order to conditionally ablate Ank in joints, including the periodontal gomphosis, Gdf5-Cre mice were crossed with mice harboring a floxed $A n k$ allele, $A n k^{f l o x P}$, as previously described [Gurley et al., 2006a]. Gdf5-Cre/AnkfloxP were prepared for 47-60 dpc. Mice were sacrificed by cervical dislocation, in accordance with the American Veterinary Medical Association Panel on Euthanasia, and approved by the Institutional Animal Care and Use Committee, University of Washington (Seattle, Wash., USA). At least three WT and KO mouse mandibles were examined for each age of interest, and three $45 \mathrm{dpc}$ Ank heterozygote mandibles were examined.

\section{Tissue Samples and Histology}

Mandibles were removed and sagittally hemisected, with one half prepared for histology and the other used for electron microscopy and nanoindenation (see methods below). Prior to processing, hemimandibles were radiographed using standard procedures for gross examination of mineralized tissues. To prepare samples for use in histology, immunohistochemistry and in situ hybridization, tissues were fixed in Bouin's solution for $24 \mathrm{~h}$, rinsed with $70 \%$ ethanol and demineralized (for post-27 dpc tissues) in acetic acid/formalin/sodium chloride solution. Tissues were processed according to standard histological procedures and embedded in paraffin. Five-micrometer buccal-lingual (frontal) sections of the first mandibular molar were prepared using a microtome and mounted as numbered serial sections on charged glass slides. Standard hematoxylin and eosin (HE) staining was used for morphological examination. High-resolution digital images were captured using Metavue software (Molecular Devices, Sunnyvale, Calif., USA) with a SPOT CCD camera (Diagnostic Instruments, Sterling Heights, Mich., USA).

\section{Histomorphometry}

Static histomorphometry was used to measure tooth root tissues in $45 \mathrm{dpc}$ sections from Ank KO and WT. From serially sectioned (buccal-lingual) 5 - $\mu$ m-thick tissues, the central 6 sections of the mesial root of the first mandibular molar were used for measurement, i.e. the central $30 \mu \mathrm{m}$ of the root. SPOT software was used to make calibrated measurements at an original magnification of $100 \times$. Measurements were made at fixed distances of 100,300 , and $500 \mu \mathrm{m}$ from the cementum-enamel junction (CEJ), 
and distances from $\mathrm{CEJ}$ to alveolar bone crest $(\mathrm{ABC})$ were determined. Measurements from the 6 sections were averaged, and a total of 3 mice each for WT and KO were used. An independentsamples (Student's) t test was employed for statistical testing using PASW (SPSS) Statistics 18 software.

\section{Tartrate-Resistant Acid Phosphatase Staining}

Tissues processed for histology were used for tartrate-resistant acid phosphatase (TRAP) staining using a commercially available kit (Sigma-Aldrich, St. Louis, Mo., USA) according to the manufacturer's instructions. Counterstaining was performed with hematoxylin.

\section{Immunohistochemistry}

For immunohistochemistry (IHC), mouse mandible tissues were deparaffinized in xylene and rehydrated in phosphate-buffered saline (PBS), using decreased graded dilutions of ethanol $(100,100,90,70$ and 50\%). Tissues were permeabilized in acetone at $-20^{\circ} \mathrm{C}$ for $10 \mathrm{~min}$, and endogenous peroxidase was quenched by incubation in $3 \% \mathrm{H}_{2} \mathrm{O}_{2}$ in methanol solution in the dark for $1 \mathrm{~h}$. Trypsin enzymatic digestion for $10 \mathrm{~min}$ at $37^{\circ} \mathrm{C}$ (Digest-All, Invitrogen, Carlsbad, Calif., USA) was used in conjunction with anti-ANK antibodies. Primary antibodies were used with biotinylated secondary antibodies (Vectastain Elite ABC, Vector Labs, Burlingame, Calif., USA) against rabbit or goat primary antibodies, as appropriate, and slides were developed using a 3-amino-9ethylcarbazole substrate kit (Vector Labs). Positive controls included antibody staining in WT tissues, where localization of target proteins has been well characterized in the mouse tooth and supporting tissues. Negative controls included normal serum or IgG in lieu of primary antibody. Primary antibodies used to react with mouse targets of interest included: three rabbit anti-mouse ANK antibodies (ANK-1, 2, and 3) [Ho et al., 2000]; LF-159 rabbit anti-mouse biglycan (a gift from Dr. Larry Fisher, National Institute of Dental and Craniofacial Research, NIDCR) [Chen et al., 2004]; rabbit anti-recombinant mouse bone sialoprotein (BSP), (a gift from Dr. Renny Franceschi, University of Michigan); LF-84 rabbit anti-mouse BSP (Dr. Larry Fisher, NIDCR) [Fisher et al., 1995]; LF-113 rabbit anti-mouse decorin (Dr. Larry Fisher, NIDCR) [Fisher et al., 1995; Schaefer et al., 1998]; rabbit anti-rat dentin matrix protein-1 (DMP1; Takara, Shiga, Japan) raised against an N-terminal (90-111) portion of DMP1; rabbit anti-rat DMP1 against an N-terminal portion (anti-DMP1-N) or C-terminal portion (anti-DMP1-C) of DMP1 (gifts from Dr. Chunlin Qin, Baylor College of Dentistry, Dallas, Tex., USA) [Maciejewska et al., 2009]; LF-153 rabbit anti-mouse dentin sialoprotein [Ogbureke and Fisher, 2004]; goat anti-human NPP1 (AbCam, Cambridge, Mass., USA); rabbit anti-human MEPE (Dr. Larry Fisher, NIDCR) [Ogbureke and Fisher, 2007]; rabbit anti-mouse osteocalcin (OCN; Takara, Shiga, Japan); LF-175 rabbit anti-mouse osteopontin (OPN; Dr. Larry Fisher, NIDCR) [Ogbureke and Fisher, 2004]. IHC for each target protein was performed in sections from at least three WT and Ank KO animals for each age, with representative staining for selected antibodies shown in the Results section.

\section{In situ Hybridization}

A modified nonradioactive in situ hybridization (ISH) protocol was used employing a digoxigenin (DIG)-labeled complementary ribonucleic acid (cRNA) probe for target genes of interest
[Jowett and Yan, 1996; Parichy et al., 2000]. Probes were used with tissues that were harvested, demineralized and embedded in paraffin as described above. Probes were linearized and purified by phenol-chloroform precipitation. Riboprobe synthesis was performed using a DIG-uridine triphosphate (UTP)-labeled kit (Roche Diagnostic Co., Indianapolis, Ind., USA). Probes were fractionated by alkaline hydrolysis at $60^{\circ} \mathrm{C}$. Riboprobe concentrations were checked by dot blot on a Hybond $\mathrm{N}^{+}$Nylon membrane (GE Healthcare, Piscataway, N.J., USA).

Sections were deparaffinized, hydrated and prehybridization (in a solution containing formamide, dextran sulfate, Denhardt's solution, and yeast transfer ribonucleic acid (tRNA)) was performed for $1 \mathrm{~h}$ at $65^{\circ} \mathrm{C}$. Hybridization was performed overnight at $65^{\circ} \mathrm{C}$ in hybridization solution $(10 \times$ salt solution, $50 \%$ deionized formamide, $50 \%$ dextran sulfate, $50 \times$ Denhardt's solution and yeast tRNA) containing the DIG-UTP-labeled sense or antisense probes. After washing in $50 \%$ formamide, $1 \times$ saline-sodium citrate, and $0.1 \%$ Tween 20 for $45 \mathrm{~min}$ at $65^{\circ} \mathrm{C}$, sections were incubated with blocking solution (10\% blocking reagent with $20 \%$ goat serum) to remove nonspecific probe binding and then with blocking solution containing a 1:2,000 dilution of anti-DIG-alkaline phosphatase (Roche Applied Sciences). Messenger ribonucleic acids (mRNAs) were detected by incubation of sections with nitroblue tetrazolium chloride/5-bromo-4-chloro-3-indolyl phosphate, toluidine salt until the desirable color intensity was reached. ISH for each target gene was performed in sections from at least three WT and Ank KO animals for each age, with representative staining for selected antibodies shown in the Results section.

Probes used for ISH: mouse Ank (provided by Dr. David Kingsley, Stanford University); mouse Dmp1 plasmid (provided by Dr. Ann George, University of Illinois, Chicago) [Hao et al., 2004]; mouse Opn and Bsp probes (provided by Dr. Marian Young, National Institutes of Health (NIH)/NIDCR) [Fisher et al., 1995]. Sense probes were used as negative controls on all tissues assayed with antisense probes.

\section{Electron Microscopy and Nanoindentation}

Scanning electron microscopy (SEM) analyses were performed on fresh, unfixed hemimandibles from $52 \mathrm{dpc}$ WT and Ank KO mice. Mandibles were sequentially dehydrated in 5, 10, $25,50,75$ and $100 \%$ aqueous ethanol solutions for $30 \mathrm{~min}$ each, then mounted in room temperature cure epoxy (Allied High Tech Inc., Rancho Dominguez, Calif., USA) to aid in handling and sample alignment. Subsequent preparation of epoxy-mounted specimens involved cutting the erupted incisor using a precision wafering saw (Buehler Ltd., Lake Bluff, Ill., USA) to expose the mesial surface of the first molar and the cross-section of the unerupted incisor. The cut surface was then ground further distally to expose the interior of the first molar using 600-then 1,500-grit silicon carbide papers, followed by smoothening via ultramicrotoming with a $45^{\circ}$-angle diamond knife (Diatome, Inc., Hatfield, Pa., USA) fitted onto an MT 6000-XL ultra-microtome (Bal-Tec RMC, Inc., Tucson, Ariz., USA). All specimens were then mounted on SEM stubs, sputter coated with $5 \mathrm{~nm}$ of Pt for electron conductivity (SPI Supplies Inc., West Chester, Pa., USA), and imaged by an JSM7000F (JEOL-USA, Inc., Peabody, Mass., USA) SEM operating at $15 \mathrm{kV}$ in backscattering mode.

Sample preparation for nanoindentation involved mounting hemimandibles in room temperature cure epoxy (Allied High 
Tech Products, Inc.), which was then cut to remove the incisor and to expose the mesial surface of the first molar using a wafering saw (Buehler, Inc.). The first molar was then ground using 400grit silicon carbide paper from the mesial side to expose the interior of the tooth until the pulp, dentin and enamel were visible simultaneously. This interior surface was further smoothened by polishing with a 1,500-grit silicon carbide paper followed by ultramicrotoming with a 2.5 -mm-wide and $45^{\circ}$-angle diamond knife (Diatome, Inc.) fitted on an MT 6000-XL ultra-microtome (Bal-Tec RMC, Inc.). Nanoindentation measurements on the specimen block were carried out using a TriboscopeTM nanoindentation unit (Hysitron, Inc., Minneapolis, Minn., USA) attached to an Autoprobe CP scanning probe microscope (Veeco, Inc., Santa Barbara, Calif., USA; formerly Park Scientific Instruments, Inc.) in air under dry conditions. Regions that qualified for indentation measurements exhibited root mean square roughness $<10 \mathrm{~nm}$ as measured by the nanoindenter (Berkovich diamond indentor with an $80-\mathrm{nm}$ tip radius). On each tooth analyzed, measurements were made on enamel, cervical dentin, and cervical cementum with 30-40 indentations on each region per tooth ( $\mathrm{n}=4$ teeth for both WT and KO), at a contact depth of approximately $100 \mathrm{~nm}$ and at least 3 contact radii apart. An independent-samples (Student's) t test was employed for statistical testing using PASW (SPSS) Statistics 18 software.

\section{Cell Culture}

Isolation and characterization of cell lines used have been previously described. In brief, OCCM.30 murine cementoblasts were obtained by enzymatic digestion from the root surface of first mandibular molars from mice expressing the SV40 large T-antigen (TAg) under control of the Ocn promoter (OC-Tag mice), allowing immortalization of Ocn-expressing cells [D'Errico et al., 2000; Berry et al., 2003]. SV11 murine PDL cells were isolated by enzymatic digestion of the heterogeneous PDL tissue from CD-1 mice and immortalized using SV40 [Berry et al., 2003]. SVF4 murine dental follicle cells were isolated by enzymatic digestion of dissected dental follicle and immortalized using SV40 [Berry et al., 2003]. MC3T3-E1 murine preosteoblasts were purchased from American Type Culture Collection (Manassas, Va., USA) and have been well characterized [Wang et al., 1999]. Cells were grown in Dulbecco's Modified Eagle Medium (DMEM) with 10\% v/v fetal bovine serum (FBS), $2 \mathrm{mM} \mathrm{L-glutamine,} 100 \mathrm{U} / \mathrm{ml}$ penicillin, and $100 \mu \mathrm{g} / \mathrm{ml}$ streptomycin (all reagents from Invitrogen). For in vitro mineralization experiments, OCCM.30 cells were plated on standard media as described above, then on day 1 , the media were switched to DMEM with $2 \% \mathrm{v} / \mathrm{v}$ FBS, $+/-50 \mu \mathrm{g} / \mathrm{ml}$ ascorbic acid (AA), and +/- $10 \mathrm{mM} \beta$-glycerophosphate (BGP, both from Sigma-Aldrich). Total RNA was isolated from cells on days 1, 3, 5, 6, 7, 8 and 9 using an RNeasy Micro kit (Qiagen, Valencia, Calif., USA) according to the manufacturer's directions. Real-time quantitative reverse transcription polymerase chain reaction (qRT-PCR) was used to analyze gene expression over time, as detailed below. To detect intergroup gene expression differences at each time point, we employed a one-way ANOVA with a post hoc Tukey test, using PASW (SPSS) Statistics 18 software.

Von Kossa staining for mineral nodule formation was done in parallel with gene expression assays, using standard procedures [Lillie, 1965]. Briefly, cells were fixed in $100 \%$ ethanol, rehydrated, and incubated with $5 \% \mathrm{AgNO}_{3}$ solution in the dark for $1 \mathrm{~h}$. The $\mathrm{AgNO}_{3}$ solution was then removed, and the plates were rinsed several times with water and placed on a light box for color development. Representative results from 1 experiment (in triplicate) out of 3 total experiments are reported.

RNA from Mouse Tissues

Total RNA was harvested from mandibular molars, calvarial bone and femurs from $34 \mathrm{dpc}$ mice. Whole molar teeth were quickly extracted with adherent periodontal tissues, and bones were harvested and overlying soft tissues manually removed and discarded. All tissues were stored unfixed at $-80^{\circ} \mathrm{C}$ until RNA was isolated. Tissues were pulverized by mortar and pestle under liquid nitrogen, followed by RNA isolation using Trizol reagent (Invitrogen), according to the manufacturer's instructions.

Real-Time Quantitative Reverse Transcription Polymerase Chain Reaction

From $1.0 \mu \mathrm{g}$ of total RNA, cDNA was synthesized (Transcriptor kit, Roche Diagnostic Co.) and $2.0 \mu$ l of the $\mathrm{CDNA}$ product was used per 20- $\mu$ l reaction in qRT-PCR using the Roche Lightcycler 480 (Roche Diagnostics GmbH, Mannheim, Germany). PCRs were carried out with the DNA Master SYBR Green I kit (Roche Diagnostic Co.). Intron-spanning primers were designed using Lightcycler primer and probe design software (http://www.geneexpression-analysis.com/). Glyceraldehyde-3-phosphate dehydrogenase (Gapdh) served as a housekeeping/reference gene for target gene normalization and gene expressions were compared using relative quantification with amplification efficiency correction for all primers. Primer sequences used are listed in online supplementary table 1 (for all online suppl. material, see www. karger.com/doi/10.1159/000323457). PCR product identification was performed by postamplification melting curve analysis. Agarose gel (1-2\% w/v) electrophoresis was additionally used to visualize product size in some cases.

\section{Results}

\section{Loss of ANK Causes Cementum Hyperplasia}

As a first step toward understanding the developmental consequences of loss of ANK, the phenotypes of Ank $\mathrm{KO}$ mouse mandible and teeth were characterized during development. Days were selected to capture developmental time points of interest, i.e. before root formation (24 $\mathrm{dpc}$ ), initiation of root/cementum formation (27 dpc), further developed root and tooth eruption (33 dpc), at completion of the root $(45 \mathrm{dpc})$, and following more than 1 month in occlusion (79 dpc).

At the macroscopic level, no obvious defects were observed in mandible or tooth development for Ank KO mice, within limits of detection. Figure 1 includes representative radiographs from WT and Ank KO hemimandibles at ages 27, 33, and $45 \mathrm{dpc}$. Molar tooth development and eruption in Ank KO appeared similar to WT for all ages. 


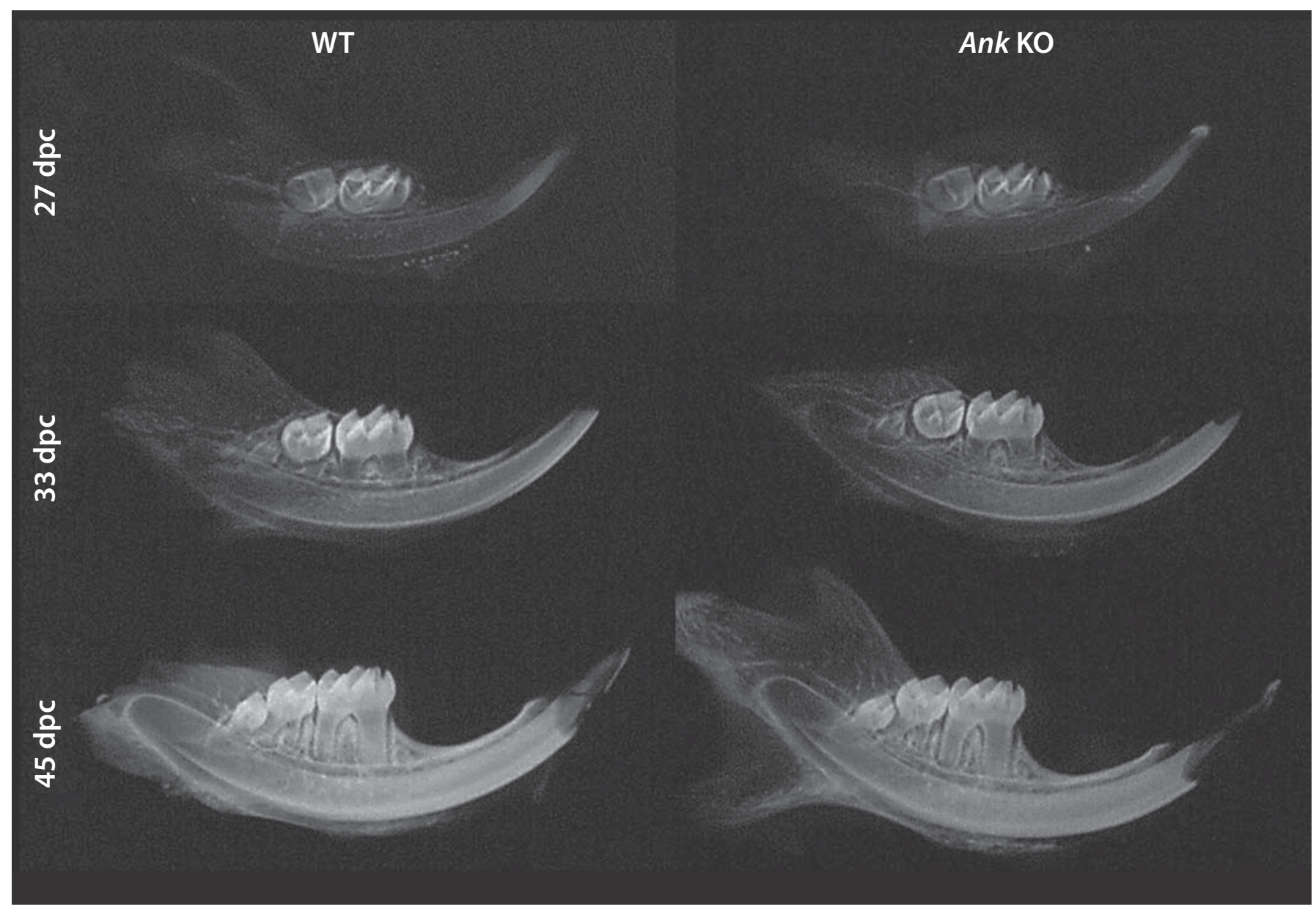

Fig. 1. Mandible development and mineralization are unaffected in Ank KO mice. Representative radiographs of hemimandibles from 27, 33, and $45 \mathrm{dpc} \mathrm{WT}$ and Ank KO mice. Within detectable limits of procedures used here, no differences were noted in Ank KO mandible or tooth development or eruption versus WT.

Detailed histological analyses of first mandibular molars and incisors were performed over the developmental course of 24-79 dpc. At the early age of $24 \mathrm{dpc}$, Ank KO molar crowns and associated tissues exhibited no apparent differences from WT (online suppl. fig. 1A, B).

With progression to root formation by $27 \mathrm{dpc}$, newly formed acellular cementum was present as a thin, basophilic layer covering the root dentin of WT molars (fig. 2A). In Ank KO mouse molars, regions of abnormally thick acellular cementum were visible under high magnification, beginning to embed adjacent cementoblasts (fig. 2B, inset). Surrounding root tissues, dental follicle, and bone appeared similar in Ank KO mice and controls.

With advanced root formation at $33 \mathrm{dpc}$, acellular cementum covered root dentin at a relatively uniform thickness in WT animals (fig. 2C). In the Ank KO mouse, the acellular cementum layer was several-fold increased (i.e. hypercementosis) compared to controls (fig. 2D). Unusually, cells were partially embedded in the cervical cementum of the Ank KO mouse. In the Ank KO, this tissue will be referred to as 'cervical cementum' as it diverged from the usual morphology of AEFC. Ank KO, dentin and bone appeared no different from WT at this age.

At $45 \mathrm{dpc}$, first-molar root development was complete, the tooth was erupted, and PDL had matured (fig. 2E, G). In the Ank KO mouse molar, cervical cementum thickness had increased (fig. 2F). The normally cell-free layer included numerous embedded cells (cementocytes) in the matrix. Ank KO apical cementum (cellular intrinsic fiber cementum) was not different from WT in regard to size or embedded cells (fig. $2 \mathrm{H}$ vs. G). The PDL space in the Ank KO mouse remained nonmineralized. By $45 \mathrm{dpc}$, an 



Fig. 2. Loss of ANK causes cementum hyperplasia. $27 \mathrm{dpc}$ : root formation was underway by $27 \mathrm{dpc}$, with cervical cementum barely visible in WT at this stage (A) while Ank KO mouse molars (B) exhibited regions of abnormally thick cementum matrix (indicated by black arrow in inset). $33 \mathrm{dpc}$ : by $33 \mathrm{dpc}$, root development advanced apically, root dentin (d) thickened, and acellular cervical cementum covered dentin in WT (C). In the Ank KO mouse (D), cervical cementum (cc) was several-fold expanded versus WT and cells were partially embedded in the matrix. $45 \mathrm{dpc}$ : in WT mice at $45 \mathrm{dpc}$, the first molar root was principally complete with both acellular (cervical) (E) and cellular (apical) (G) cementum (ac). In the Ank KO mouse molar, the widened cervical cementum (F) included numerous cell inclusions (cementocytes). PDL space (p) was maintained. Conversely, $\mathrm{KO}$ apical cementum $(\mathbf{H})$ was not different from WT. Apical cementum is marked by a dotted red outline. All images are from lingual side of first mandibular molar. Scale bars represent $100 \mu \mathrm{m}(\mathbf{A}-\mathbf{F})$ or $200 \mu \mathrm{m}(\mathbf{G}, \mathbf{F}) . \mathrm{dp}=$ Dental pulp; DF = dental follicle; $\mathrm{b}=$ bone. 
apparent reduction in lingual alveolar bone height was noticed, as described further in the following section.

Importantly, at $79 \mathrm{dpc}$, with the first molar in functional occlusion for more than 1 month, the cervical cementum thickness had continued to expand in Ank KO, yet the PDL space remained well maintained, comparable to age-matched WT controls (online suppl. fig. 1C, D). Alveolar bone reduction in Ank KO had advanced further by this age, a trend explored in more detail in the next section. This finding is in contrast to severe ectopic calcification found in joints of $A n k \mathrm{KO}$ mice at this age [Gurley et al., 2006a].

Examination of mandibular second and third molars revealed thick cervical cementum on these teeth. Crosssections of the continually erupting mouse incisor exhibited cementum on the lingual 'root analogue' aspect, which was the acellular variety (online suppl. fig. 2A, C, E). Like the cervical cementum of the molar, the Ank KO incisor tooth exhibited a hypercementosis phenotype that was visible by $27 \mathrm{dpc}$ and increasingly expanded versus WT over subsequent time points (online suppl. fig. 2B, $D, F)$. As with the molar, the dentin, pulp chamber and PDL of the incisor did not appear different from WT. Examination of thick cementum on both molars and incisor root analog indicates an intrinsic alteration in acellular cementum development.

\section{The PDL Space in Ank KO Is Maintained by Alveolar \\ Bone Remodeling}

Histomorphometry was employed to detect and quantify any subtle changes in the dimensions of cementum and determine whether surrounding tissues were altered. Developmental age $45 \mathrm{dpc}$ was chosen in order to measure molars at a mature root stage where teeth were erupted and PDL had become functional and organized. Measurements were made on histological sections cut in the buccal-lingual (frontal) direction, at distances of 100, 300 and $500 \mu \mathrm{m}$ measured apically from the CEJ, the anatomical transition between crown and root. Tissues measured included alveolar bone, PDL, cervical cementum, dentin, predentin and pulp chamber.

Cervical cementum in Ank KO mice was significantly thicker than in WT at all 3 points measured $(\mathrm{p}<0.01$ for all comparisons), on both buccal and lingual aspects of the tooth root (fig. 3). Ank KO cementum was from 8- to 12 -fold thicker than in WT at the 3 points. Other tissues measured were not different in $\mathrm{KO}$ versus $\mathrm{WT}$, with the notable exception that PDL was found to be slightly increased in Ank KO versus WT (significant on lingual aspect at $300 \mu \mathrm{m}$ and buccal aspect at $500 \mu \mathrm{m}$ ), a finding contrary to expectations in light of the widened cementum. Results from incisors paralleled those from molars, where cementum was significantly increased in Ank KO versus WT, (approximately 10 -fold, $\mathrm{p}<0.005$ ), while other tissues were not altered. In both molars and incisors of Ank KO, measured dimensions of dentin, predentin, and pulp were similar to WT. Mean measurements and statistical analyses can be found in online supplementary table 2 .

Histological examination indicated alteration of the alveolar bone around the first molars of Ank KO mice, therefore measurement of the distance from CEJ to $\mathrm{ABC}$ (the most coronal portion of the alveolar bone proper) was performed. Measurements confirmed a greater CEJ$\mathrm{ABC}$ distance on both lingual and buccal sides (fig. 3B). The combination of bone alteration and maintenance of PDL width suggested PDL width was maintained by increased bone remodeling in Ank KO mice. TRAP staining confirmed approximately 3 -fold increased numbers of TRAP-positive osteoclast-like cells on the alveolar bone proper (adjacent to PDL and tooth root) of both buccal and lingual alveolar bone in Ank KO versus WT (fig. 3D vs. C). Further, identification of reversal lines in lingual alveolar bone (aided by immunohistochemical labeling of OPN) signified new bone apposition on the outer aspect of alveolar bone (fig. 3F), while WT bone tended to show apposition on both inner and outer aspects (fig. 3E). Altogether, maintenance of PDL and evidence for alveolar bone remodeling supports a role for PDLbone interactions in order to accommodate increased cementum width in Ank KO molar teeth.

Though PDL was maintained around Ank KO molars, tissue masses consistent with cementicles (cementumlike masses forming in the PDL region) were observed in Ank KO mouse PDL, always localized to the most cervical portion of PDL on the buccal side, and separate from cementum and bone (data not shown). The late appearance and consistent localization of these cementicles suggest they result from some type of functional response rather than being a developmental defect.

\section{Mineralization and Mechanical Properties of \\ Dentoalveolar Tissues Are Unchanged in Ank KO Mice}

Next, SEM in backscatter (BSE) mode was used to assess whether the quality of cementum formed was compromised in Ank KO versus WT. BSE mode indicates relative material density where a brighter image denotes denser material, reflecting composition and elemental content. BSE images from WT and Ank KO first molars in the cer- 

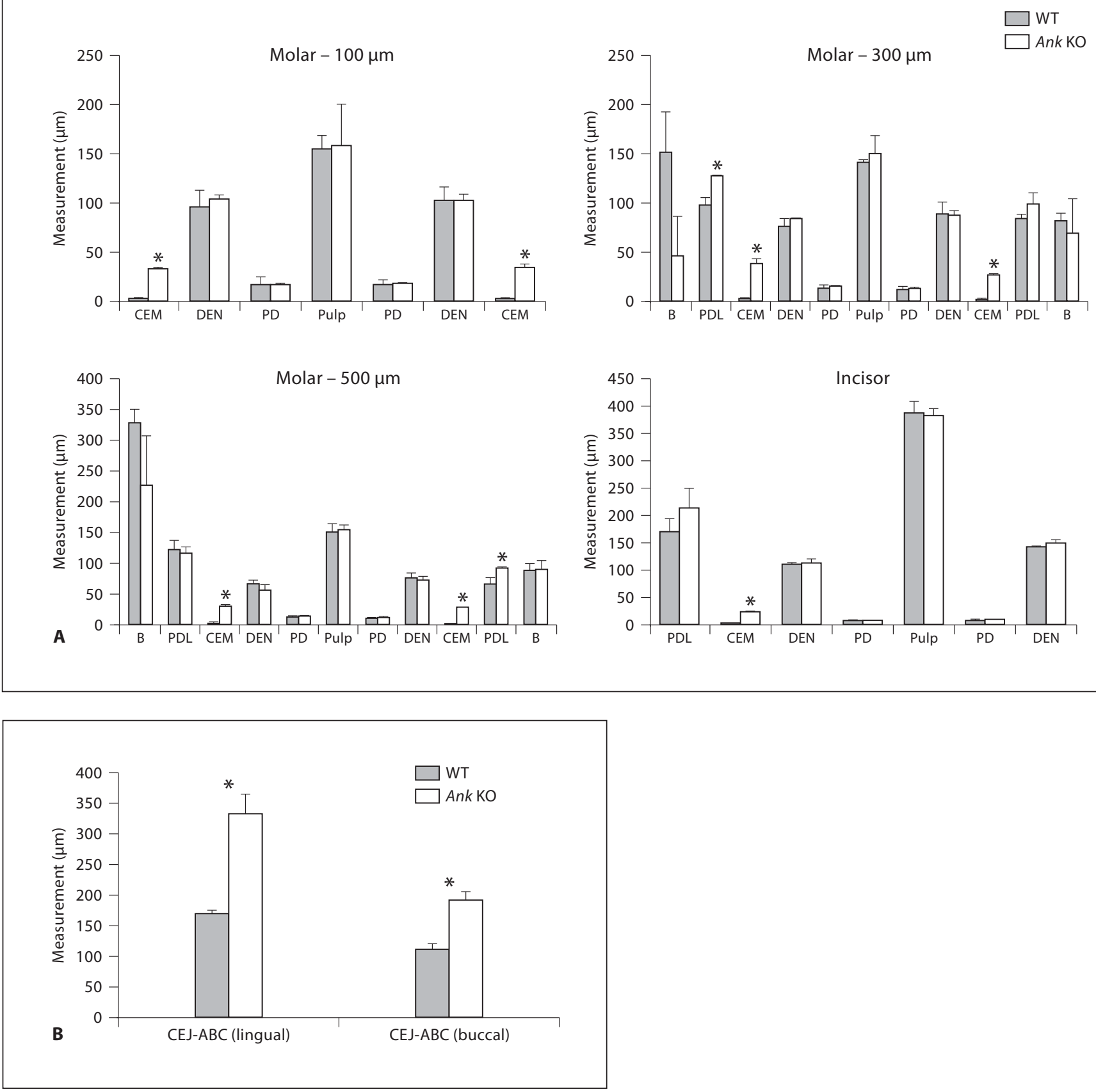

TRAP staining

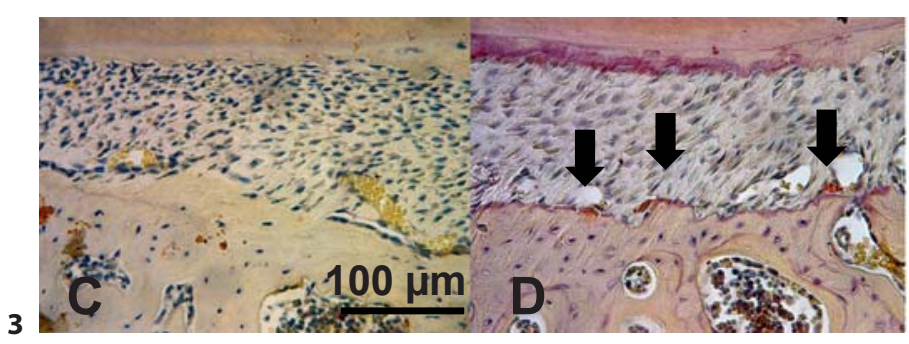

Osteopontin IHC

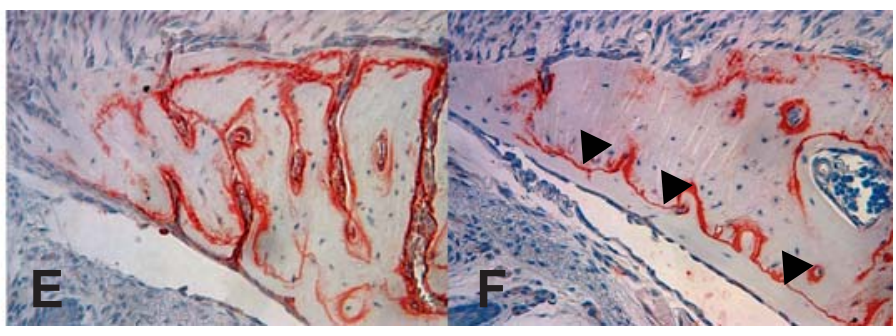

Foster et al. 
vical regions in both groups are shown in figure 4A, B. Enamel, being the most mineralized, appeared brightest in both WT and KO. Dentin and cementum share similar composition and mineral content, and thus appeared at similar gray level contrast in SEM images. Within the limits of detection, no major difference was observed in any Ank KO mineralized tissues compared to $\mathrm{WT}$, indicating that relative mineralization was likely not different.

Mechanical properties of the mineralized dental tissues of WT and Ank KO were assessed by nanoindentation. No measureable differences were found in hardness $(\mathrm{H})$ or reduced elastic modulus $\left(\mathrm{E}_{\mathrm{r}}\right)$ of cementum between WT $\left(\mathrm{H}=0.6 \pm 0.2 \mathrm{GPa} ; \mathrm{E}_{\mathrm{r}}=24 \pm 3 \mathrm{GPa}\right)$ and $A n k$ $\mathrm{KO}$ cervical cementum $\left(\mathrm{H}=0.7 \pm 0.2 ; \mathrm{E}_{\mathrm{r}}=25 \pm 3\right)$, as summarized in figure $4 \mathrm{C}$, D. Likewise, no significant difference was detected in WT versus $\mathrm{KO}$ comparisons of dentin and enamel.

\section{Loss of ANK Alters Cementoblast Gene Expression and Cervical Cementum Extracellular Matrix Composition}

IHC and ISH were used to characterize expression of selected cementum, bone and dentin markers (i.e. miner-

Fig. 3. Histomorphometry confirms unique sensitivity of cementum to loss of ANK. A Measurements were made on $45 \mathrm{dpc}$ molars (where tooth development was largely completed) at apical distances 100, 300, and $500 \mu \mathrm{m}$ from the CEJ. Tissues measured included (listed from lingual to buccal across tooth in left to right direction): alveolar bone (B), PDL, cementum (CEM), dentin $(\mathrm{DEN})$, predentin $(\mathrm{PD})$, pulp chamber, predentin, dentin, cementum, PDL and alveolar bone. Cervical cementum in Ank KO mice was significantly thicker ( 8 - to 12 -fold) than in WT at all 3 points measured $(\mathrm{p}<0.01)$, and on both lingual and buccal aspects. PDL was slightly increased in Ank KO versus WT, significantly on the lingual aspect at $300 \mu \mathrm{m}$ and buccal aspect at $500 \mu \mathrm{m}$, while all other tissues measured were not found to be different in KO versus WT. Incisor cementum was significantly altered in Ank KO, increased approximately 10 -fold $(\mathrm{p}<0.005)$. Other tissues (listed from labial to lingual direction) including PDL, dentin, predentin, and pulp were not different in KO versus WT. * Indicates significance by independent-samples Student's t test, $\mathrm{p}$ value $<0.05$. B Measurements made from the CEJ to the ABC confirmed a greater $\mathrm{CEJ}-\mathrm{ABC}$ distance on both lingual and buccal sides. WT alveolar bone proper (C) showed few TRAP-positive cells, while Ank KO bone (D) supported increased numbers of TRAP-positive osteoclast-like cells (arrows) on lingual alveolar bone proper, indicating increased bone remodeling in Ank KO. WT alveolar bone (E) featured apposition on both inner and outer aspects (as marked by OPN IHC), while prevalent reversal lines (F, arrowheads) in Ank KO suggested bone apposition on the outer aspect of lingual alveolar bone. Scale bar in C represents $100 \mu \mathrm{m}$.

Cementum Phenotype in Ank KO Mice alized tissue extracellular matrix proteins and their respective genes) in Ank KO and WT controls. Figure 5 shows representative staining in $\mathrm{WT}$ and $\mathrm{KO}$ tissues, where $45 \mathrm{dpc}$ was used to examine matrix produced over the course of cementogenesis, and the earlier age of 33 $\mathrm{dpc}$ was used to assay gene expression in situ during active cementum formation. Online supplementary figure 3 provides lower-magnification IHC images at 33, 45, and $79 \mathrm{dpc}$ to illustrate the distribution of proteins in the periodontal region over a developmental to functional time course.

BSP was localized to bone matrix and acellular and cellular cementum (fig. 5A and online suppl. fig. 3) [MacNeil et al., 1995; McKee et al., 1996]. In acellular cementum, BSP, a characteristic marker for this tissue, was present as a concentrated band defining the entire width of the cementum layer. The thick Ank KO cervical cementum showed positive, but diffuse BSP staining, with some localization in the initial cementum, but not through the entire thickness (fig. 5B, online suppl. fig. 3). Results were consistent with two separate BSP antibodies, as well as following antigen retrieval using trypsin digestion (data not shown). Staining of BSP in bone and cellular cementum was similar between Ank KO and controls. ISH revealed equivalent $B s p$ mRNA expression in cementoblasts and osteoblasts in $33 \mathrm{dpc}$ WT (fig. 5C) and Ank KO (fig. 5D) tissues.

OPN protein, a known marker for acellular cementum, was observed in bone matrix, PDL, and in acellular and cellular cementum (fig. 5E and online suppl. fig. 3) [Bronckers et al., 1994; MacNeil et al., 1995; McKee et al., 1996]. OPN localization in Ank KO was notable for the strong, even immunostaining throughout the entire cervical cementum thickness, and high expression in cementoblasts lining the root (fig. 5F). Increased OPN protein in Ank KO was also apparent by $33 \mathrm{dpc}$, and strong OPN localization in cervical cementum continued through $79 \mathrm{dpc}$ (online suppl. fig. 3). In WT, Opn mRNA was localized to osteoblasts and some cementoblasts, especially those apically located on the molar where cementogenesis was ongoing (fig. 5G). In Ank KO, Opn was intensely expressed by cementoblasts lining the entire root (fig. $5 \mathrm{H}$ ), confirming increased and sustained $O p n$ versus WT molars. Opn levels in other cells and tissue in Ank $\mathrm{KO}$, including osteoblasts, resembled WT.

DMP1 protein in WT was localized primarily to bone matrix around osteocytes (fig. 5I), with lower levels of staining apparent around some cementocytes in the apical cementum (online suppl. fig. 3) [Butler et al., 2002; Feng et al., 2003; Baba et al., 2004; Qin et al., 2007; Ye et 

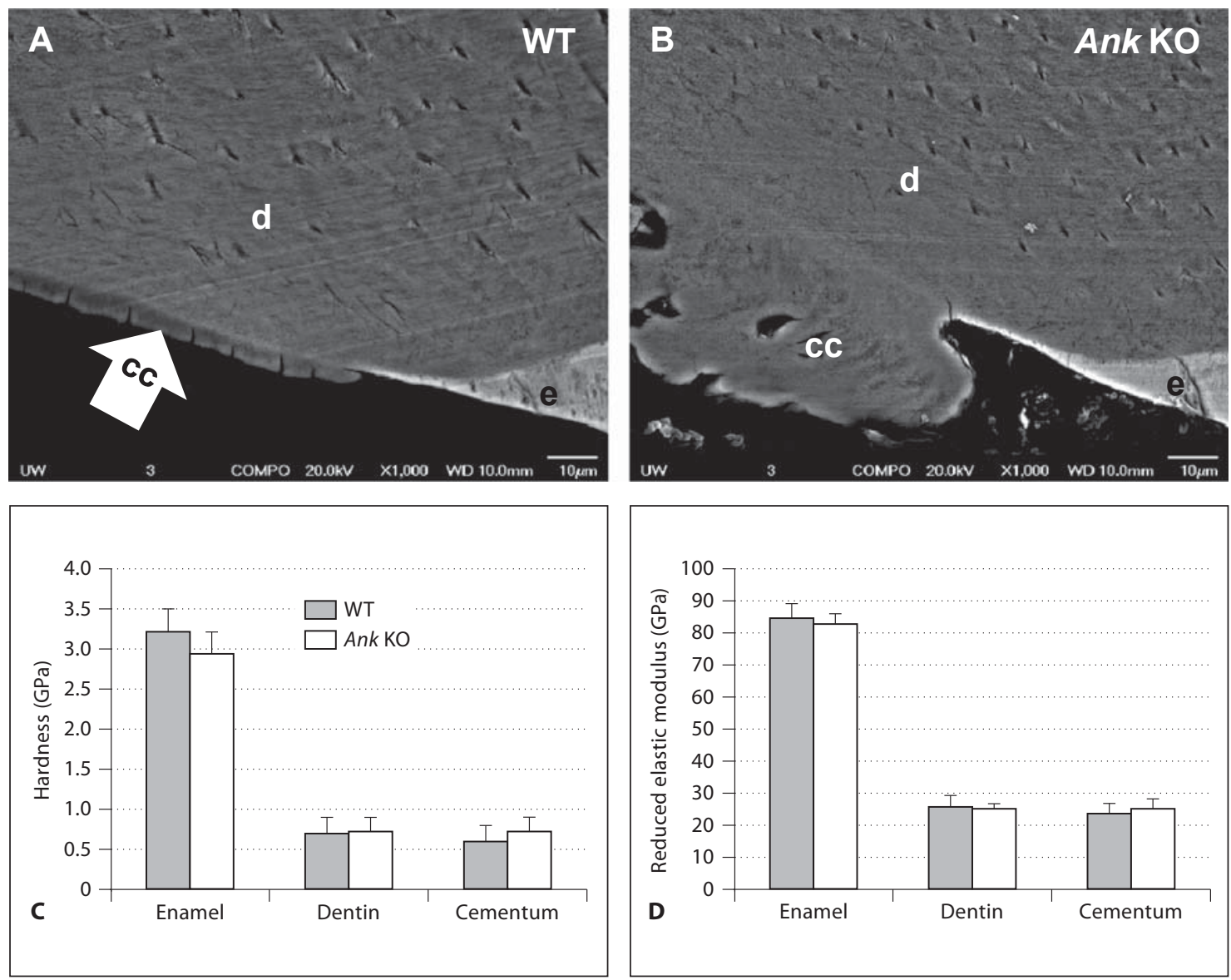

Fig. 4. Mineralization and mechanical properties of dentoalveolar tissues are unchanged in Ank KO mice. SEM in BSE indicated no discernible difference in WT (A) versus Ank KO (B) mineralized tissues, suggesting percent mineralization and/or composition was not different within the limits of detection used here. Nanoindentation measurements indicated no detectable differences in hardness $(\mathrm{H})(\mathbf{C})$ or reduced elastic modulus $\left(\mathrm{E}_{\mathrm{r}}\right)(\mathbf{D})$, between WT $\left(\mathrm{H}=0.6 \pm 0.2 \mathrm{GPa} ; \mathrm{E}_{\mathrm{r}}=24 \pm 3 \mathrm{GPa}\right)$ and $A n k \mathrm{KO}(\mathrm{H}=0.7 \pm 0.2$ $\mathrm{GPa} ; \mathrm{E}_{\mathrm{r}}=25 \pm 3 \mathrm{GPa}$ ) molar cementum. Likewise, no difference was detected in WT versus KO comparisons of dentin and enam$\mathrm{el}$, as determined by independent-samples Student $\mathrm{t}$ test, $\mathrm{p}$ value $<0.05$. Scale bars in $\mathbf{A}, \mathbf{B}$ represent $10 \mu \mathrm{m}$. al., 2008]. WT acellular cementum was not immunopositive for DMP1. In Ank KO, DMP1 was heavily localized to the cervical cementum, especially perilacunar spaces around embedded cells, and in cells in the process of being embedded in cementum (fig. 5J). As with OPN, increased DMP1 was apparent by prefunctional age 33 $\mathrm{dpc}$, and the trend continued through $79 \mathrm{dpc}$. DMP1 staining in Ank KO cementum was even more intense than in bone, where DMP1 localization is usually greatest. Results were confirmed with 3 different DMP1 antibodies used, including N-terminal and C-terminal targeted antibodies. By ISH, Dmp1 mRNA was identified in WT odontoblasts and osteocytes (fig. 5K), while transcripts were clearly increased in cementoblasts along the molar root of the Ank $\mathrm{KO}$ mouse (fig. 5L). In contrast, $D m p 1$ message levels were unchanged in odontoblasts, osteoblasts and osteocytes of Ank KO versus WT.

All protein findings from Ank $\mathrm{KO}$ mouse molars were consistent with staining in the incisor (online suppl. fig. 4). Ank $\mathrm{KO}$ incisor cementum featured increased DMP1 protein and limited BSP compared to WT, while OPN immunostaining was robust in both WT and KO.

Several other extracellular matrix proteins were assayed by IHC and found to be no different in Ank KO versus WT (data not shown). These included OCN, dentin sialoprotein, MEPE, decorin, biglycan, and periostin. 


\section{Immunohistochemistry} WT
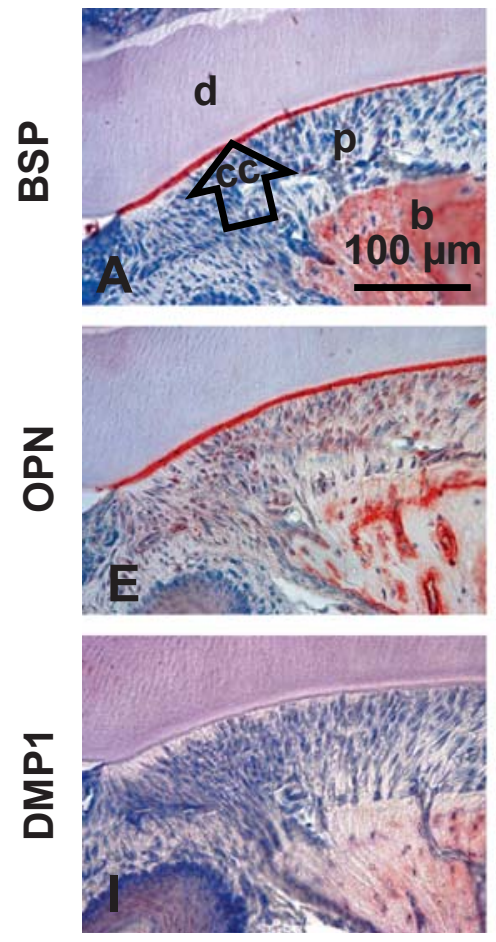

Ank KO
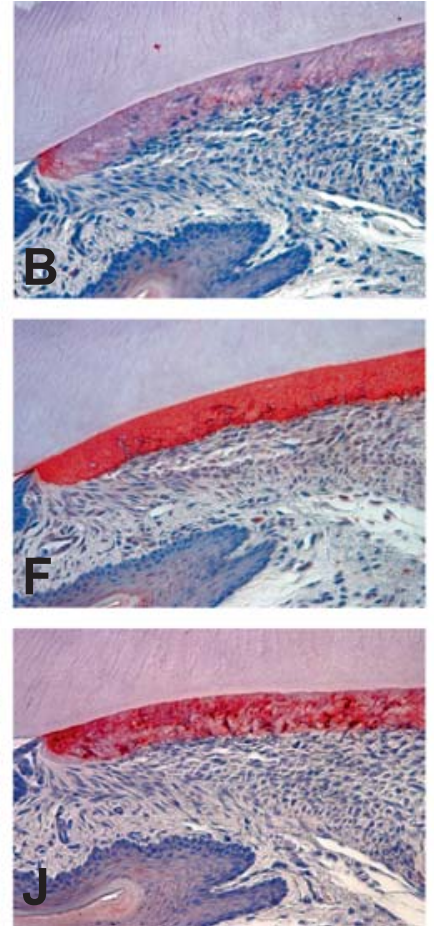

Fig. 5. Loss of ANK alters cementoblast gene expression and cervical cementum extracellular matrix composition. Histological sections from $45 \mathrm{dpc}$ mice were used for IHC, while $33 \mathrm{dpc}$ tissues were used for ISH. BSP: in WT (A), BSP protein staining was strong in bone (b) and defined the entire acellular cementum (cc). Ank KO cervical cementum (B) showed diffuse and limited BSP staining. ISH revealed Bsp mRNA expression in cementoblasts and osteoblasts in WT tissues (C). Ank KO cementoblasts expressed similar levels of Bsp mRNA (D). OPN: in WT (E), OPN was observed at bone cement lines, in PDL (p), and strongly labeled acellular cementum. OPN localization in $\mathrm{KO}(\mathbf{F})$ was similar to WT, with cervical cementum exhibiting strong and even OPN labeling. Opn mRNA expression was localized to bone-lining osteoblasts and some cementoblasts, especially those apically locat-

\section{In situ hybridization}

WT
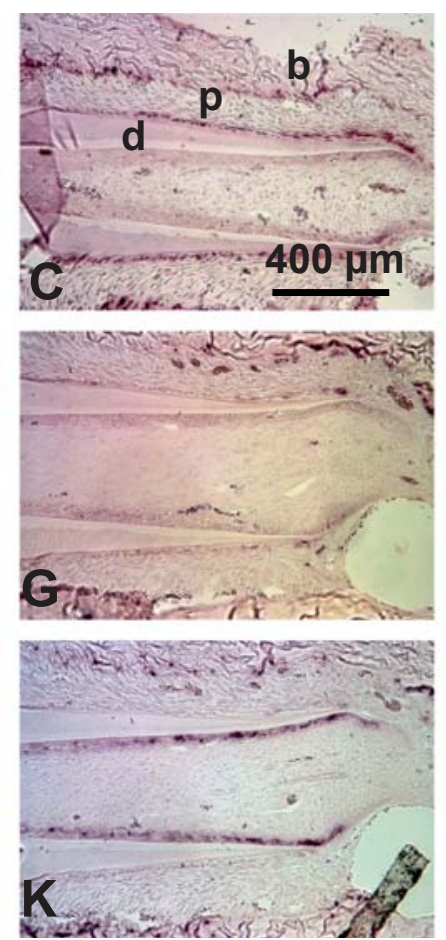

Ank KO
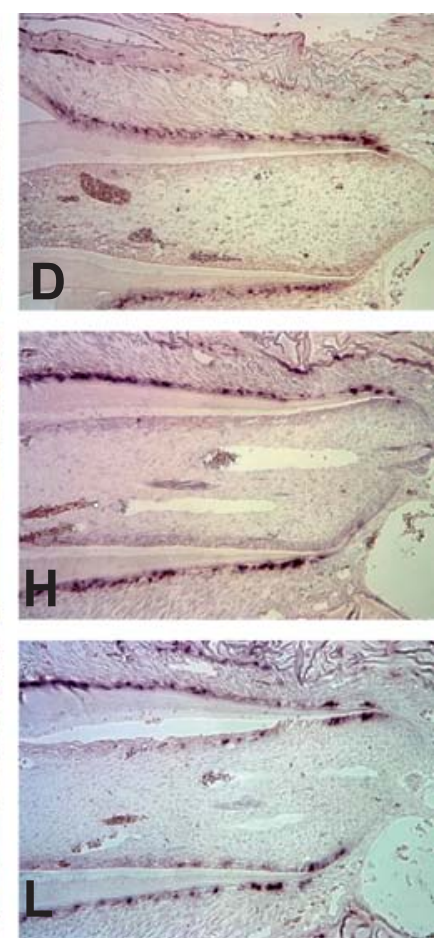

ed (G). In Ank KO, Opn mRNA was intensely expressed by cementoblasts lining the entire (cervical) cementum (H). DMP1: DMP1 in WT (I) was localized to bone around osteocytes, but not acellular cementum. In Ank KO (J), DMP1 was strongly localized to cervical cementum, particularly to perilacunar spaces around cells. By ISH, Dmp1 mRNA was identified in WT odontoblasts and osteocytes (K). Dmpl message was clearly increased in cementoblasts/cementocytes along the molar root of the Ank KO mouse, but levels were not different in odontoblasts, osteoblasts and osteocytes of Ank KO versus WT (L). For IHC, lingual aspect of mandibular first molar is featured; see online supplementary figure 3 for overall protein distributions in the dentoalveolar complex. Scale bars represent $100 \mu \mathrm{m}$ in A, B, E, F, I and J, and $400 \mu \mathrm{m}$ in $\mathbf{C}, \mathbf{D}, \mathbf{G}, \mathbf{H}, \mathbf{K}$ and $\mathbf{L}$. $\mathrm{d}=$ Dentin.

complex at 33 dpc. ANK was localized to ameloblasts, cells of the pulp, odontoblasts, cells of the follicle and developing PDL, cementoblasts, osteoblasts, and some osteocytes (fig. 6). This ubiquitous expression of ANK in the tooth agrees with previous reports demonstrating the presence of Ank message in many organ systems [Ho et al., 2000]. No special localization of ANK was noted in cementoblasts or cementum-associated PDL, though its widespread presence could make localized selective expression difficult to identify. The specificity of ANK 

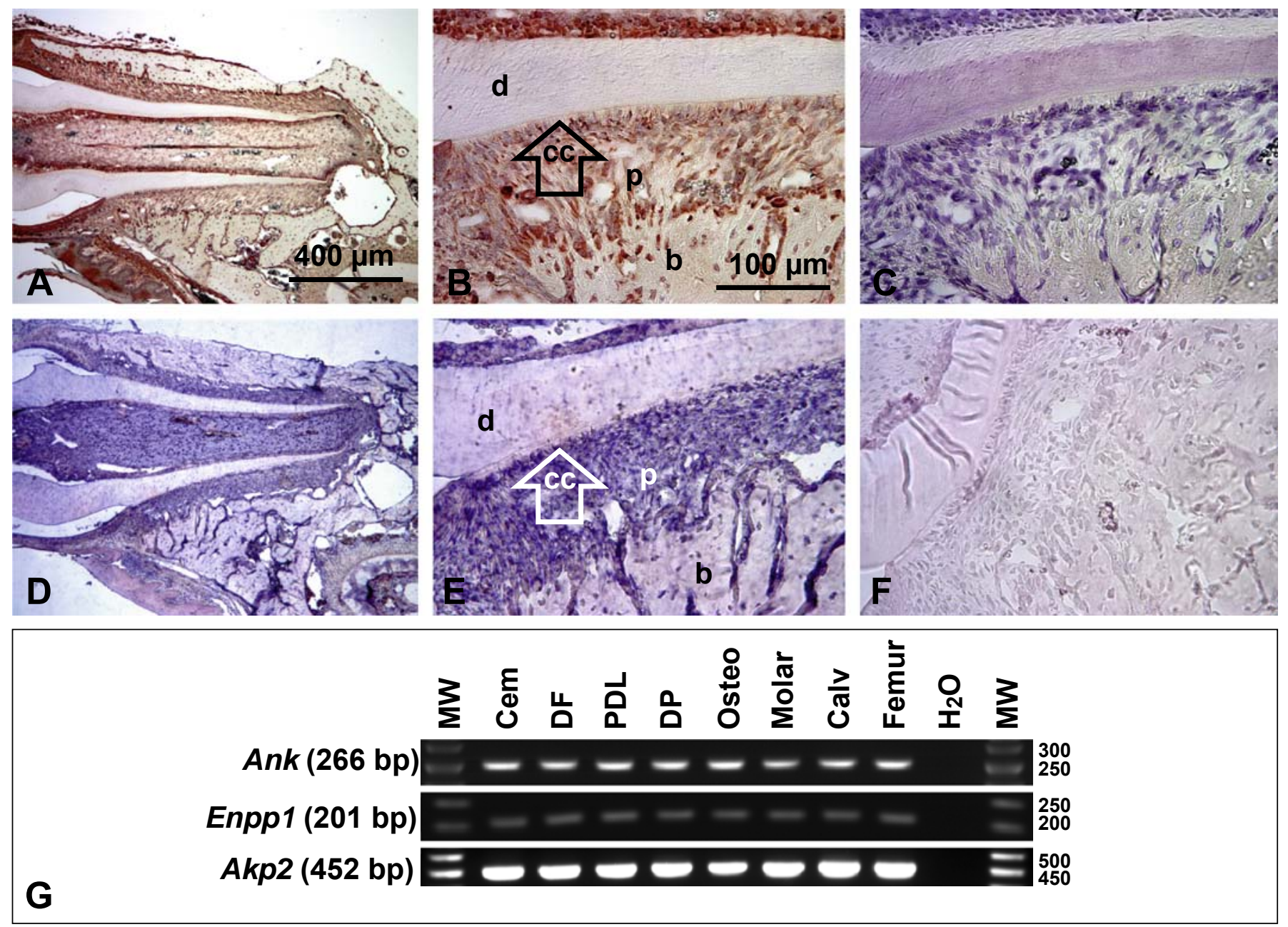

Fig. 6. ANK is widely expressed during tooth root development. A, B In $33 \mathrm{dpc}$ WT molars, ANK protein staining was observed in cells and tissues of the developing dentoalveolar complex, e.g. ameloblasts, odontoblasts, PDL, cementoblasts, osteoblasts and osteocytes. These representative images were from use of ANK-3 antibody; results with additional ANK antibodies are shown in online supplementary figure 5 . While ANK staining was widespread in tooth tissues, it was not matched in negative controls (C) or Ank
KO sections (online suppl. fig. 5). (D, E). In situ hybridization for Ank mRNA in $33 \mathrm{dpc}$ WT tissues confirmed widespread immunohistochemical results whereas sense negative controls were not stained (F). Scale bars represent $400 \mu \mathrm{m}$ in $\mathbf{A}$ and $\mathbf{D}$, and $100 \mu \mathrm{m}$ in B, C, E and F. G Tooth-derived cells and tissues express Ank, Enpp1, and Akp2: Cementoblasts (Cem), dental follicle (DF), PDL cells, primary dental pulp (DP) cells, pre-osteoblasts (Osteo), and whole mouse molar, calvaria (Calv), and femur RNA preparations. staining was confirmed by using negative controls for IHC and ISH (fig. 6), as well as multiple antibodies in WT and Ank KO (online suppl. fig. 5). To further confirm IHC and ISH results by an independent assay, we analyzed tooth-associated cell types for mRNA expression of $A n k$, while also testing for Enpp1 and $A k p 2$ (TNAP gene) expression. All cell lines robustly expressed $A n k$, Enpp1 and $A k p 2$ as determined by RT-PCR (fig. 6G). While limited to gross tissue level of resolution, RT-PCR performed on RNA harvested from whole mouse molars established Ank, Enpp1 and Akp2 expression at the tissue level, in vivo, confirmed by positive reactions from mouse calvariae and femurs. Thus by multiple parallel techniques, $A n k, A k p 2$ and Enpp1 were found to have wide-ranging expression in tooth cells and bone tissues.

NPP1 Is Increased in Cementoblasts in Ank KO Mice

To determine whether loss of ANK altered expression of the parallel $\mathrm{PP}_{\mathrm{i}}$ regulator NPP1, IHC for NPP1 was 

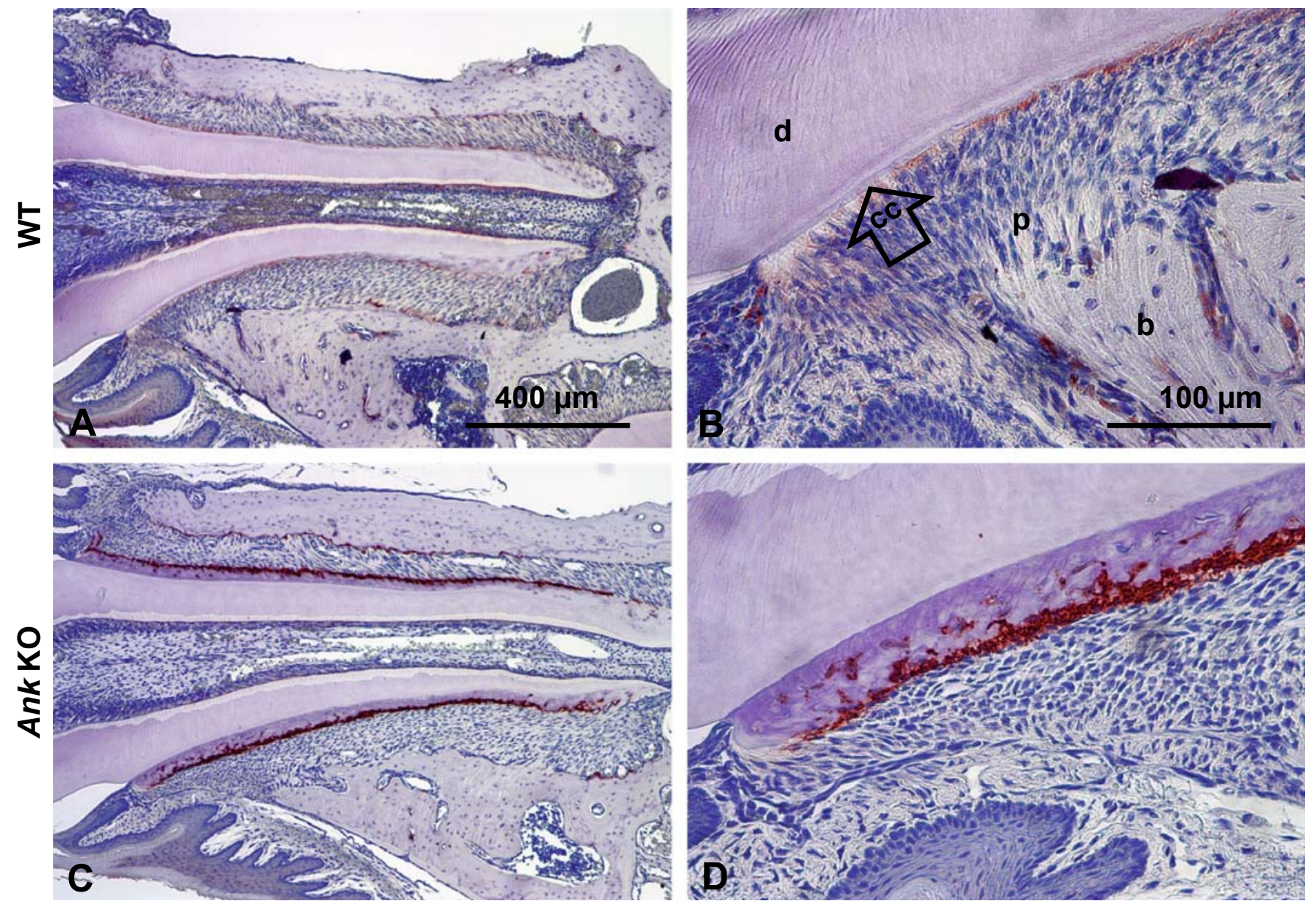

Fig. 7. NPP1 is more highly expressed by cementoblasts during tooth development and increased in Ank KO cementoblasts. A, B In 45 dpc WT molar, NPP1 staining was observed most strongly in cementoblasts, but was present at low levels in osteoblasts, odontoblasts and some PDL cells. C, D In Ank KO molars,
NPP1 was remarkably increased in cementoblasts lining the root, as well as some cells embedded in the thick cementum, though expression was not different in other cells of the dentoalveolar complex. Scale bars represent $400 \mu \mathrm{m}$ in $\mathbf{A}$ and $\mathbf{C}$, and $100 \mu \mathrm{m}$ in B and $\mathbf{D}$. $\mathrm{d}=$ Dentin; $\mathrm{cc}=$ cervical cementum; $\mathrm{p}=\mathrm{PDL}$; $\mathrm{b}$ bone. performed. While low-level immunostaining of NPP1 was apparent in odontoblasts, osteoblasts and in some cells in the PDL, a discreet region of higher-intensity staining was apparent in cementoblasts lining the molar root in WT (fig. 7A, B). Compared to WT, NPP1 expression was remarkably increased in Ank KO cementoblasts lining the cervical root as well as those cells embedded in cementum (fig. 7C, D). In stark contrast to intense expression by Ank KO cementoblasts, NPP1 expression was similar in Ank KO osteoblasts, odontoblasts, or other cells, as compared to WT.
Conditional Loss of ANK Confirms Local Function in Cementogenesis

Ank is widely expressed in the body and in the dentoalveolar complex; therefore, in order to analyze whether loss of ANK is a systemic or local influence on the periodontium, conditional $\mathrm{KO}$ mice were prepared by crossing Gdf5-Cre-expressing mice with mice harboring a floxed $A n k$ allele (Ank floxP $)$. Gdf-5, a member of the transforming growth factor- $\beta$ superfamily, is expressed in articular tissues, including the developing PDL [Morotome et al., 1998; Sena et al., 2003].

As described previously for joints [Gurley et al., 2006a], Gdf5-Cre-Ank ${ }^{\text {floxP }}$ tissues exhibited variable 


\section{Control}
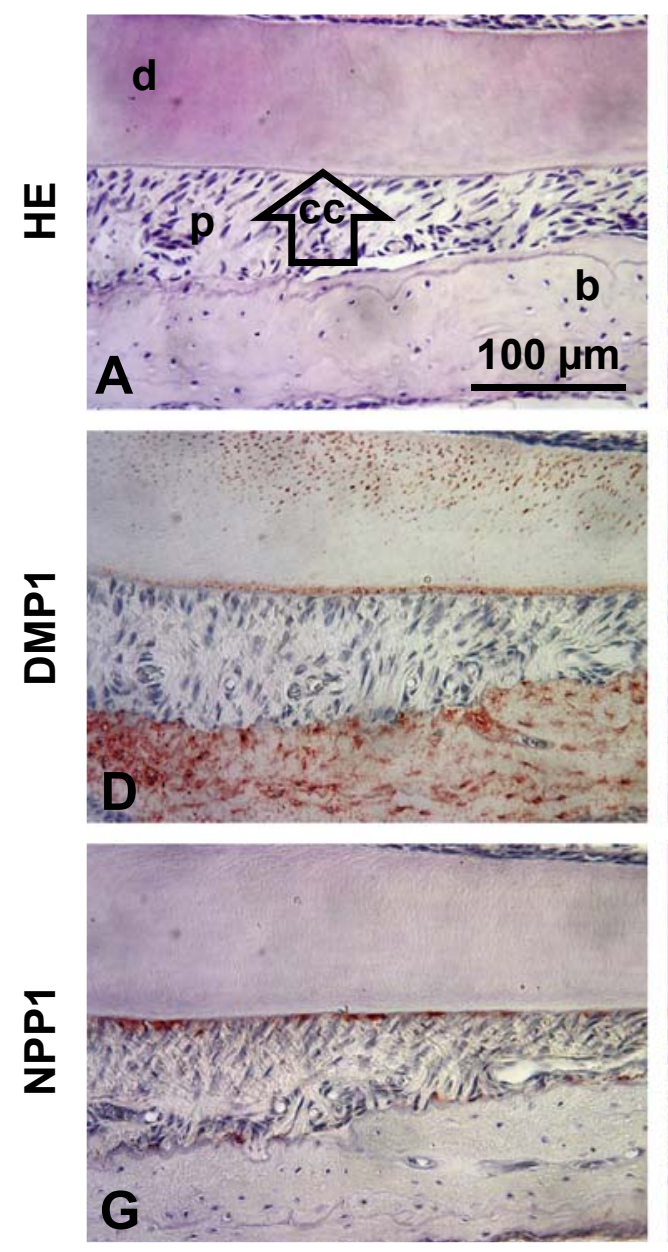

Gdf5-Cre-AnkfloxP mild phenotype
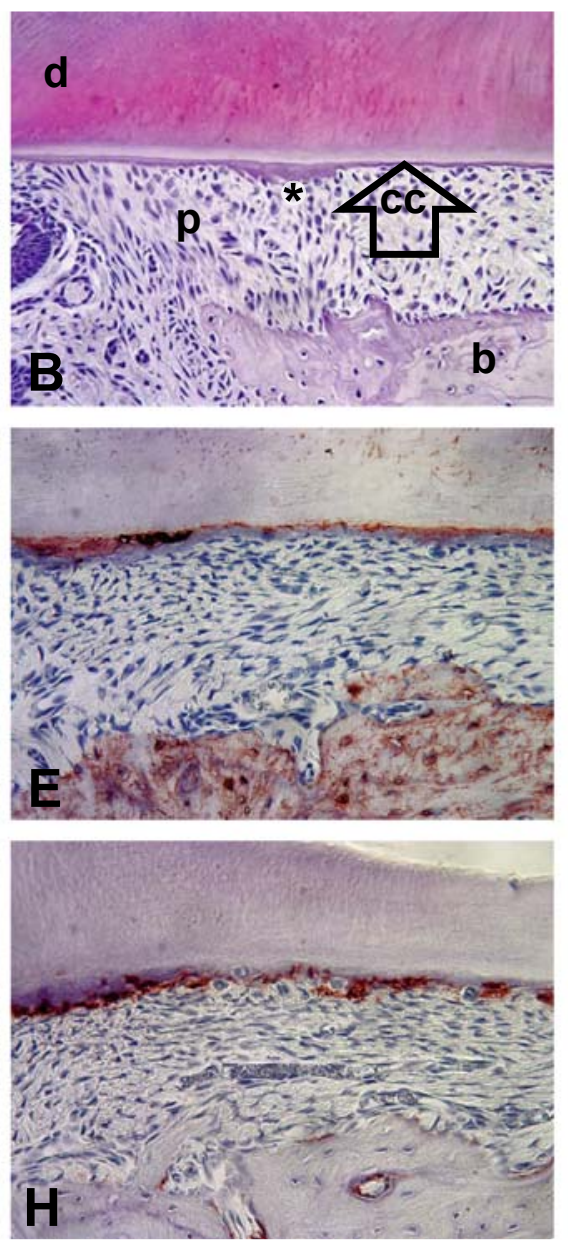

Gdf5-Cre-AnkfloxP severe phenotype
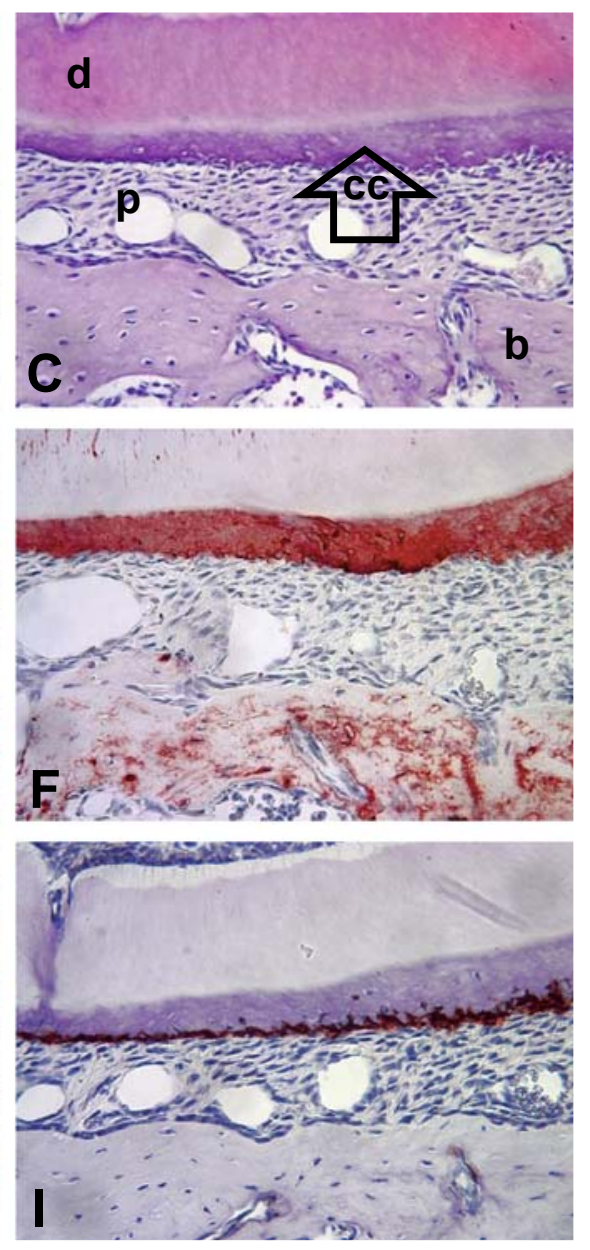

Fig. 8. Conditional loss of ANK confirms local function in cementogenesis. Compared to control molars (A), conditional KO of Ank in Gdf5-Cre-Ank floxP resulted in mild phenotypes (B) marked by slight cementum (cc) thickening and local hypercementosis $\left(^{*}\right)$ or severe phenotypes (C) mimicking the global Ank KO. While WT acellular cementum was negative for DMP1 (D), increased DMP1 was found in areas of thickened cementum in mildly affected $G d f 5-C r e-A n k^{f l o x P}$ molars (E), and in all cervical cementum in severely affected $G d f 5-C r e-A n k^{\text {floxP }}$ molars (F). WT cementoblasts expressed NPP1 weakly (G), but upregulation was found in cementoblasts of mildly affected Gdf5-Cre-Ank floxP molars $(\mathbf{H})$, and stronger up regulation in cementoblasts of severely affected Gdf5-Cre-Ank floxP molars (I). All images are representative examples chosen from the cervical portion of the mesial root of fully developed first molars, with buccal-lingual sectioning used for A, B, D, E, G, and $\mathbf{H}$, and mesial-distal sectioning used for $\mathbf{C}, \mathbf{F}$, and $\mathbf{I}$. HE = Hematoxylin-eosin staining. Scale bars in $\mathbf{A}-\mathbf{I}$ represent $100 \mu \mathrm{m} . \mathrm{d}=$ Dentin; $\mathrm{p}=\mathrm{PDL} ; \mathrm{b}=$ bone. phenotypic severity resulting from variation in extent of recombination. Mildly affected $G d f 5-C r e-A n k^{\text {floxP }}$ mice $(n=6)$ exhibited a slight but consistent increase in acellular cementum thickness versus controls, with occasional localized regions of hypercementosis (fig. 8A, B). Severely affected Gdf5-Cre-Ank $k^{\text {floxP }}$ mice $(\mathrm{n}=4)$ exhibited uniformly thick cementum indistinguishable from the global Ank KO (fig. 8C). The ability for Gdf5-conditional Ank KO to recapitulate the cementum phenotype confirmed a local role for ANK in regulating cementum.

DMP1 and NPP1 were assayed in Gdf5-Cre-Ank floxP mice because of their markedly increased expression in cementoblasts in the global Ank KO. In mildly affected 
Gdf5-Cre-Ank floxP molars, DMP1 staining in AEFC was primarily associated with regions of most increased thickness, while regions of thin cementum remained negative for DMP1 (fig. 8D, E). Regions of increased NPP1 were found in all mildly affected Gdf5-Cre-AnkfloxP molars, but ass for DMP1, the most intense NPP1 staining was consistently associated with increased AEFC apposition (fig. 8G, H). DMP1 and NPP1 staining in severely affected Gdf5-Cre-Ank floxP molars mimicked that seen in global Ank KO (fig. 8F, I).

\section{Ank and Enpp1 Are Expressed by Cementoblasts}

Coincident with in vitro Mineralization

Based on expression of ANK gene/protein and NPP1 protein in tooth cells at about the time of cementogenesis and the demonstration that ANK must function locally in cementoblast cells, in vitro experiments using OCCM.30 murine immortalized cementoblast cells were performed to determine whether these genes were expressed in temporal fashion during mineral formation. OCCM. 30 cells were cultured in control media (DMEM with $2 \%$ FBS), media supplemented with $50 \mu \mathrm{g} / \mathrm{ml} \mathrm{AA}$, or mineralization media, which included $50 \mu \mathrm{g} / \mathrm{ml} \mathrm{AA}$ and $10 \mathrm{mM} \mathrm{BGP}$, for up to 10 days, with RNA isolated for gene expression (1, 3, 5-9 days) and von Kossa staining used in parallel samples to assay mineral nodule formation.

Cementoblasts incubated with mineralization media produced visible matrix by day 6 , with beginnings of mineralized nodules by day 7 , and increased staining at days 8-10 (fig. 9A). Cells receiving control media or AA alone did not produce mineral nodules. Expression of $A k p 2$ peaked at day 3 , during the early period of culture, consistent with the role of TNAP as an early bone/cementum marker involved in matrix modification prior to mineralization (fig. 9B) [Lian and Stein, 1992]. Early, intense $A k p 2$ expression required both AA and BGP (mineralizing conditions). Control or AA groups increased $A k p 2$ slowly over the culture period, but did not produce mineral nodules. In contrast, Opn expression was dramatically increased (more than 60 -fold over day 1 ) at onset of mineralization on days $6-7$, a trend previously reported in osteoblast cultures [Owen et al., 1990; Lian and Stein, 1992]. Notably, increased Opn occurred only in the presence of AA and BGP, where mineral nodules were forming. Induction of $O p n$ in concert with mineral accumulation is consistent with OPN as a regulator of HAP mineralization.

As observed for Opn expression, Ank and Enpp1 were induced at the onset of mineralization, both peaking at days $6-7$, and only under mineralizing conditions. Ank levels reached $150 \%$ of day 1 levels, while Enpp1 peaked at $600 \%$ of day 1 levels. Results suggested Ank and Enpp1 were functionally coupled with mineralizing conditions, i.e. induction of these genes required formation of mineralized matrix. More specifically, the timing of gene expression and requirement for mineralizing media supported ANK and NPP1 as regulators of cementoblast extracellular matrix mineralization. In addition to a more dramatic increase for Enpp1 versus Ank during mineralization, relative levels of Enpp1 mRNA were much higher than Ank, more than 1,000-fold relative units (as normalized to Gapdh). Relatively high expression of Enpp1 mRNA in cementoblasts is in agreement with in vivo IHC observations of elevated NPP1 along the tooth root.

\section{Discussion}

The aim of these studies was to further define the unique role of the $\mathrm{PP}_{\mathrm{i}}$ regulator ANK during cementogenesis. We demonstrate that ANK serves as a critical regulator of tooth root acellular cementum, and profoundly contributes to shaping the development of the tissue. Ank KO resulted in loss of regulation of cementum apposition, causing exceptionally thick cervical cementum. While ANK was found to be widely expressed in the dentoalveolar complex, the dentin, enamel and apical cellular cementum were not affected in the KO. We report here for the first time that loss of ANK caused altered cementoblast gene expression, including increased $O p n$ and Dmp1. Notably, the dramatically increased DMP1 coincided with greater cementum thickness and embedded cells in Ank KO cervical cementum. Ank KO cementoblasts further showed remarkably increased NPP1 expression, suggesting attempted compensation for low extracellular $\mathrm{PP}_{\mathrm{i}}$ levels. Intriguingly, NPP1 was unaltered in bone and dentin in Ank KO. Conditional KO of ANK function in PDL confirmed a local role for ANK and $\mathrm{PP}_{\mathrm{i}}$ in controlling cementogenesis, and linked increased apposition with increased DMP1 and NPP1 expression.

These results have implications for fundamental mechanisms controlling cementogenesis. Firstly, the divergent responses of acellular (cervical) and cellular (apical) cementum to Ank KO point to different developmental influences on these two cementum types. Under conditions of ANK deficiency, acellular cementum approximates a cellular cementum-like tissue, and therefore physiologic regulation of local $\mathrm{PP}_{\mathrm{i}}$ serves in part to define the acellular type of cementum. Secondly, the ob- 

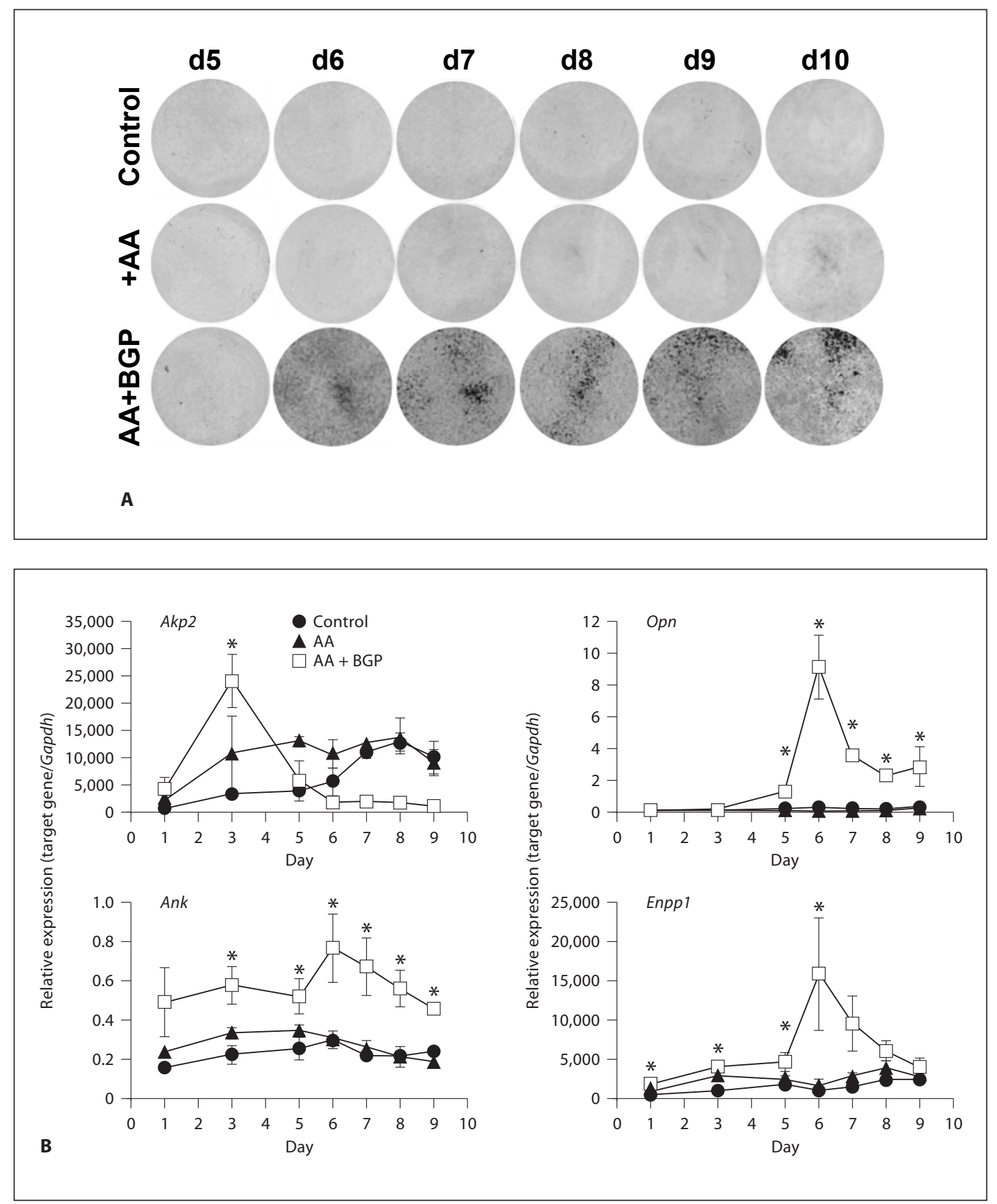

Fig. 9. Ank and Enppl are expressed during the mineralization stage of cementoblasts, in vitro. Studies with OCCM.30 cementoblasts were performed to characterize the temporal developmental sequence of gene expression resulting in matrix mineralization. Von Kossa staining indicated mineralized nodule formation by days 6-7, with increased staining at days 8-10 (A). B OCCM.30 gene expression was assayed in parallel to mineralization. Akp2 peaked early at day 3 , during the period prior to mineralization, and required AA and BGP for early intense induction. Increased mRNA for Opn required AA and BGP for maximal induction, which took place in parallel to mineralization, at days 6-7. Both Ank and Enppl induction depended on mineralizing conditions and occurred coincidentally with mineralization. Graphs show mean \pm SD for 3 samples. ${ }^{*}$ Indicates significant intergroup differences determined by one-way ANOVA and post hoc Tukey analysis, where mineralizing conditions (AA + BGP) induced significantly greater gene expression versus nonmineralizing conditions (control or AA only). Complete statistical analyses can be found in online supplementary table 3 . 
served alterations in apposition and gene and protein expression in Ank KO cervical cementum, but not seen in apical cementum, bone and dentin, point to unique developmental influences on AEFC versus other mineralized tissues. These analyses confirm the hypothesis that acellular cementum formation is sensitive to local $\mathrm{PP}_{\mathrm{i}}$ metabolism, but importantly, also demonstrate that cementoblasts in vivo are sensitive to changes in local $\mathrm{PP}_{\mathrm{i}}$ and respond in a unique way by altering expression of proteins which regulate $\mathrm{PP}_{\mathrm{i}}$ homeostasis and matrix mineralization.

\section{ANK Control of Pyrophosphate Governs Acellular Cementum Apposition}

These data on $A n k \mathrm{KO}$, in conjunction with previous studies on $\mathrm{PP}_{\mathrm{i}}$ regulators and odontogenesis, identify $\mathrm{PP}_{\mathrm{i}}$ as an important regulator of the acellular cementum. ANK is widely expressed and likely participates in proper development of mineralized tissues and joints in the body, as well as being involved in inhibition of nonphysiological calcification in soft tissues in mice and humans [Hessle et al., 2002; Harmey et al., 2004; Malkin et al., 2005; Murshed et al., 2005]. Our studies indicated ANK is expressed by several cells and tissues during tooth development. Despite no special pattern of expression of Ank gene or ANK protein in cementoblasts, evidence presented here demonstrates that development of the tooth root acellular (cervical) cementum critically relies on local ANK function. ANK is proposed to primarily regulate transport of $\mathrm{PP}_{\mathrm{i}}$ from the intracellular to extracellular space [Ho et al., 2000; Gurley et al., 2006b]; this suggests that $\mathrm{PP}_{\mathrm{i}}$ plays a central role in controlling cementogenesis. A similar hypercementosis resulting from lack of NPP1 activity (also creating $\mathrm{PP}_{\mathrm{i}}$ deficiency) confirms that decreased $\mathrm{PP}_{\mathrm{i}}$ is the mechanism for increased cementum formation [Nociti et al., 2002]. This type of role for $\mathrm{PP}_{\mathrm{i}}$ is in line with findings that TNAP activity in the PDL is highly correlated to acellular cementum thickness [Groeneveld et al., 1995], and loss of TNAP causes cementum aplasia or severe hypoplasia [Beertsen et al., 1999; van den Bos et al., 2005].

How does $\mathrm{PP}_{\mathrm{i}}$ regulate cementogenesis? The first way is by controlling the rate at which acellular cementum grows. Loss of ANK results in faster AEFC apposition from the beginning of root formation onwards. The unusual cellularity of the cervical cementum in Ank KO molars is likely a result of this increased rate of apposition. Under normal circumstances, the 'slow' physiologic rate of acellular cementum formation lags that of the rapidly forming apical cellular cementum [Bosshardt and
Schroeder, 1990]. With loss of ANK, the ability of cervical cementoblasts to set a controlled appositional rate is lost, and the acellular cementum exceeds its normal boundary. The ability of $\mathrm{PP}_{\mathrm{i}}$ concentration to 'tune' cementum thickness was shown by Gdf5-Cre-AnkfloxP conditional Ank KO, where incomplete recombination led to incomplete ablation of ANK, and an AEFC phenotype between WT and the global Ank KO. This idea is in line with $\mathrm{PP}_{\mathrm{i}}$ (which is low in $A n k \mathrm{KO}$ ) as regulator of HAP, and these findings support ANK as an important 'negative' regulator of acellular cementum development. In contrast, cellular cementum is not $\mathrm{PP}_{\mathrm{i}}$ dependent, as it was morphologically and histochemically unchanged by Ank KO, and was also reported to be less affected by loss of TNAP [Beertsen et al., 1999; van den Bos et al., 2005].

The divergent response in acellular versus cellular cementum underscores the importance of $\mathrm{ANK}$ and $\mathrm{PP}_{\mathrm{i}}$ regulation as one of the defining differences between development of these two tissues. A fundamental question, therefore, is why acellular and cellular cementogenesis are differently regulated by $\mathrm{PP}_{\mathrm{i}}$. We speculated that acellular cementogenesis depends more upon directed mineralization of PDL fibers inserting into the root, a process highly susceptible to physiochemical modulation by $\mathrm{PP}_{\mathrm{i}}$. In contrast, cellular cementum formation, like bone and dentin, follows a two-step process whereby an unmineralized matrix is first produced and secondarily mineralized, and this sequence is more directly dependent on cellular matrix synthesis. This hypothesis has arisen from previous reports of the process of cementogenesis [well summarized in Bosshardt and Schroeder, 1996], and the observations in the Ank KO tooth corroborate this idea.

Results from Ank $\mathrm{KO}$ also call attention to properties of the PDL. Importantly, even in the face of exuberant cementum formation in Ank KO molars, PDL width was maintained by remodeling of alveolar bone. This finding is quite intriguing in light of reports of impaired osteoclast production from Ank mutant mouse bone marrow cells [Kim et al., 2010], and offers further evidence that the PDL (essentially a type of joint called a gomphosis) is subject to unique functional regulation versus joints of the axial and appendicular skeleton, where loss of ANK resulted in severe ectopic calcifications [Ho et al., 2000; Harmey et al., 2004; Gurley et al., 2006a]. In considering the significance and balance of form versus function for the periodontal complex in Ank KO, cervical cementum continues on its developmental trajectory while expansion of the root volume in turn prompts PDL to regulate alveolar bone architecture. It is useful to contemplate 
these observations by further considering the two softhard interfaces of the tissue compartments involved, namely cementum-PDL and PDL-bone.

Prior to eruption, AEFC forms as a thin tissue on the root surface, and does not undergo remodeling during life, but grows at a slow pace year by year. The proximal signals and mechanisms directing AEFC formation remain largely unresolved [Bosshardt, 2005; Foster et al., 2007]. With loss of $A N K$ and $P_{i}$ dysregulation, AEFC expanded past WT by 27-33 dpc, well before tooth eruption, organization of PDL and functional occlusion. We interpret this to mean that ANK plays an important role in the developmental program for acellular cementum, primarily helping define the border between the mineralized cementum and nonmineralized ligament. The steady expansion of AEFC between 45 and $79 \mathrm{dpc}$ seems to be a continuation of the developmental increase in apposition, outside of any significant functional influence. One of the limitations of this study is that we focused predominantly on developmental time points, only up to 2 months after birth, so we cannot speculate on how the loss of ANK would affect long-term periodontal maintenance or response to trauma. The more bone-like cellular cementum also does not remodel per se, but is responsive to functional changes and requirements of the tooth, such as to maintain occlusion [for example, Luan et al., 2007]. Based on these studies, again limited by a focus on development, we conclude that ANK does not play a large role in directing cellular cementum formation or homeostasis after birth.

The high capacity of the PDL for homeostasis by remodeling, including the precise maintenance of PDL width, has been well established [as reviewed in McCulloch et al., 2000]. The PDL is maintained as a nonmineralized ligament between two hard tissues, even while harboring cells with osteoprogenitor (and cementoprogenitor) potential. PDL resists ectopic mineralization and ankylosis by its high capacity for remodeling, and via the ability of PDL cells to regulate neighboring alveolar bone, which is also subject to high turnover [Beertsen et al., 1997; Pavlin and Gluhak-Heinrich, 2001; Fleischmannova et al., 2010]. For example, preservation of PDL width by regulation of bone apposition and resorption has been documented after orthodontic force applications [Shimono et al., 2003; Wise and King, 2008]. It is notable that in the context of loss of ANK and $\mathrm{PP}_{\mathrm{i}}$ homeostasis, the cementum-PDL hard-soft interface is relocated, but the PDL proper persists due to bone remodeling. These observations suggest that (1) ANK aids in defining the cementum PDL-border, but not the PDL width or PDL-bone border, and (2) PDL can respond to cementum encroachment, maintaining width and fulfilling functional requirements of load bearing, by paracrine regulation of alveolar bone. The ability for PDL proper to remain unmineralized in conditions of $A n k \mathrm{KO}$ points to the presence of other factors within the PDL space that work to prevent mineralization, likely including both negative regulators of mineral growth and factors that indirectly prevent mineralization by influencing cell differentiation [McCulloch et al., 2000]. The Ank KO mouse provides a model for identifying factors regulating PDL or PDL-cementum interface, which may aid development of agents for use in preventing ectopic calcifications in joints and elsewhere.

\section{Acellular Cementum Is a Pyrophosphate-Sensitive}

Tissue

Further evidence for $\mathrm{PP}_{\mathrm{i}}$ regulation of acellular cementum comes from cementoblast cell gene and protein expression. While ANK is expressed in the tooth and associated tissues, NPP1, another $\mathrm{PP}_{\mathrm{i}}$ regulator, is more highly expressed in cementoblasts in vivo than other cells of the dentoalveolar complex. We demonstrate for the first time in vivo that NPP1 increased as a result of Ank $\mathrm{KO}$, and the increased expression is specifically localized to the cementoblasts. We hypothesize this reaction is an attempt to correct low $\mathrm{PP}_{\mathrm{i}}$ or rapid cementum apposition, and increased NPP1 associated with regions of thicker cementum in Gdf5-Cre-Ank ${ }^{\text {floxP }}$ supports this association. This type of compensation has not been previously described in other tissues and can be interpreted as evidence that cementoblasts detect and respond to $\mathrm{PP}_{\mathrm{i}}$ levels. In Ank KO teeth, even the observed overexpression of NPP1 was apparently not sufficient to compensate for reduced $\mathrm{PP}_{\mathrm{i}}$. Perhaps cementoblasts require both $\mathrm{ANK}$ and NPP1 to adequately regulate the extent of cementum formation. This observation agrees with previous assertions that ANK and NPP1 function in nonredundant fashion to impact extracellular $\mathrm{PP}_{\mathrm{i}}$ levels [Harmey et al., 2004]. If increased NPP1 cannot compensate, this prompts questions of how ANK and NPP1 functions may interact, as well as whether there is sufficient substrate availability to supply NPP1 activity.

A role for $\mathrm{PP}_{\mathrm{i}}$ production as a mechanism to regulate cementum matrix mineralization was further indicated by in vitro studies. In cementoblast cultures, both Ank and Enpp1 gene expressions were induced by mineralizing conditions at onset of mineralization, implying a functional coupling of these factors with mineralization. This trend parallels results from osteoblasts, where in- 
duction of mineralization regulators such as $O p n$ and Ocn depended upon elaboration of mineralized matrix [Owen et al., 1990]. Continued mechanistic studies with cementoblasts will shed further light on the role and regulation of these proteins in cementogenesis.

\section{Loss of ANK Alters Cementum Matrix Composition}

by Affecting Cementoblast Gene Expression

Loss of ANK caused changes in extracellular matrix of cervical cementum but not other tissues in our experiments. For BSP, OPN, and DMP1, these gene/protein changes were observed by $33 \mathrm{dpc}$, prior to tooth eruption and function. The early timing of these changes suggests they could result directly from the $\mathrm{PP}_{\mathrm{i}}$ imbalance, or from the associated change in cementum apposition, in the Ank KO. These possibilities are developed more fully in the following paragraphs.

The most striking change was increased DMP1 in Ank KO cervical cementum versus WT. The likely mechanism for increased cementum DMP1 is revealed by expression patterns and function of this protein. Under normal conditions, DMP1 production is highest in osteocytes of the bone [Toyosawa et al., 2001] and is found in the similarly embedded cementocytes of the cellular cementum [MacDougall et al., 1998; Feng et al., 2003; Ye et al., 2008]. DMP1 is important for the canalicular systems of both osteocytes and cementocytes [Ye et al., 2008], possibly via its role in response to mechanical loading [Gluhak-Heinrich et al., 2003; Yang et al., 2004, 2005; Amir et al., 2007], or by regulating HAP mineralization [Gajjeraman et al., 2007]. Thus, the increase in Dmp1 gene expression and DMP1 protein secretion into cementum matrix in the Ank KO mouse is hypothesized to be the result of more rapid apposition and cell inclusion, i.e. a transition from acellular cementum to cellular-type cementum. Selective increase of DMP1 only in regions of thicker cementum of mildly affected Gdf5-Cre-Ank floxP molars supports this hypothesis.

BSP is a classical marker for bone and cementum [MacNeil et al., 1995; McKee et al., 1996], proposed as a nucleator of HAP crystal and thus a positive regulator for mineralization [Hunter and Goldberg, 1994; Harris et al., 2000]. Ank KO cervical cementum showed limited BSP staining, in contrast to WT, where concentrated BSP defines the entire acellular cementum width. However, $B s p$ mRNA was undiminished in Ank KO cementoblasts lining the root. Therefore, in Ank KO cervical cementum, BSP protein concentration may be reduced in the relatively larger volume of cementum, i.e. a 'dilution' effect. Like DMP1, BSP belongs to the small integrin-binding ligand, N-linked glycoprotein (SIBLING) protein family [Fisher and Fedarko, 2003; Qin et al., 2004] thought to influence matrix mineralization [Fantner et al., 2007]. Increased DMP1, while BSP protein remains limited, could reflect transition from what is usually a thin 'surface' tissue to a thick mineralized tissue harboring cementocytes analogous to osteocytes of bone. The implications of such a cell switch from a 'blastic' to a 'cytic' type of cell are currently under study.

OPN, another SIBLING protein family member, is an inhibitor of HAP precipitation [Hunter et al., 1994; Gericke et al., 2005] found in bone and cementum, as well as soft tissues, where it prevents ectopic calcification [Bronckers et al., 1994; MacNeil et al., 1995; McKee et al., 1996; Giachelli, 2005]. We show here that OPN protein is richly present in the cervical cementum of the Ank KO mouse. At least some portion of cementum OPN can originate from circulation [VandenBos et al., 1999], but ISH studies showed upregulated and sustained Opn mRNA in cementoblasts along the entire molar root in Ank KO, while Opn message in WT was limited to apical areas of active cementogenesis. Increased cementum OPN was unexpected because of previous reports on Ank mutant and Enpp1 null mice that OPN production by osteoblasts and in bone and articular surfaces was decreased [Johnson et al., 2003; Harmey et al., 2004, 2006]. Authors hypothesized that by changing $\mathrm{PP}_{\mathrm{i}}$ concentrations, $\mathrm{ANK}$ and other $\mathrm{PP}_{\mathrm{i}}$ regulators tuned $\mathrm{OPN}$ expression and controlled mineralization. This sort of multifunctional role for $\mathrm{PP}_{\mathrm{i}}$ in controlling mineralization is supported by in vitro studies where $\mathrm{PP}_{\mathrm{i}}$ increased osteoblast Opn expression and regulated TNAP function [Addison et al., 2007]. Our finding of strong OPN in the Ank $\mathrm{KO}$ tooth is counter to previous observations of OPN reduction in other skeletal tissues, and points to a different regulation of cementogenesis versus other skeletal sites. We hypothesize that the observed increases in both OPN and NPP1 are attempts by cementoblasts to control cementum apposition, though it remains a fascinating question why $\mathrm{KO}$ cementum continues to expand. One possibility is that cementogenesis requires carefully regulated harmonious expression of ANK, NPP1 and OPN.

The concept has arisen that $\mathrm{P}_{\mathrm{i}}$ and $\mathrm{PP}_{\mathrm{i}}$, and the local ratio of $\mathrm{P}_{\mathrm{i}} / \mathrm{PP}_{\mathrm{i}}$, affect not only the physiochemical process of HAP mineralization, but also affect cell phenotype in a unified mechanism whereby $\mathrm{P}_{\mathrm{i}}$ and $\mathrm{PP}_{\mathrm{i}}$ concentrations influence cell differentiation, gene expression, matrix production and mineralization. $\mathrm{P}_{\mathrm{i}}$ and $\mathrm{PP}_{\mathrm{i}}$ both elicit altered gene expression in mineralizing cells in culture, suggesting signaling roles for these ions [Beck et al., 2000; 
Beck, 2003; Johnson et al., 2003; Harmey et al., 2004; Foster et al., 2006; Rutherford et al., 2006; Addison et al., 2007; Fatherazi et al., 2009]. In vitro, exogenous $P_{i}$ added to cementoblasts increased Dmp1 and Opn gene expression while $B s p$ was decreased [Foster et al., 2006; Fatherazi et al., 2009]. It is therefore notable that when ANK is ablated, decreased $\mathrm{PP}_{\mathrm{i}}$ (and increased $\mathrm{P}_{\mathrm{i}} / \mathrm{PP}_{\mathrm{i}}$ ratio) is associated with increased cementoblast DMP1 and OPN and limited BSP.

\section{Implications for ANK in Oral Health and Cementum Regeneration Therapies}

At present, the physiological role of ANKH in human tooth formation remains unclear because of lack of detailed case reports. In a dental case report on a young CMD patient, we described ectopic mineral on maxillary molars which was not inconsistent with the mineral accumulation in Ank KO mice teeth [Zhang et al., 2007]. A mouse model phenocopying CMD was successfully created by knocking in the human $A N K H$ mutation responsible for CMD, though tooth development was not detailed [Chen et al., 2009]. Additionally, a novel ANKH mutation has recently been identified in 6 patients from a family of Turkish ethnicity, all featuring joint pain and restricted movement similar to Ank mutant and $\mathrm{KO}$ mice [Morava et al., 2010]. Intriguingly, developmental tooth abnormalities were reported in these patients, though detailed phenotypes were not available. The question of whether $A N K H$ plays an equivalent role in human cementogenesis is an area for further investigation.

In addition to providing new insights on cementum development, these studies may also provide information useful for therapeutic strategies. Periodontal disease can lead to severe loss of bone, PDL and cementum. While great strides have been made in therapeutic approaches for repairing bone and PDL in these cases, cementum regeneration has proven to be unpredictable, even with addition of progenitor cells and factors to promote differentiation [Giannobile and Somerman, 2003; Bashutski and Wang, 2009]. Based on findings here and from other studies, the acellular cementum appears to be especially sensitive to local $\mathrm{PP}_{\mathrm{i}}$ concentration. An approach targeting modulation of $\mathrm{PP}_{\mathrm{i}}$ in the periodontal region has the potential to promote cementogenesis, and could be used in tandem with other approaches involving delivery of cells or bioactive factors to provide an environment conducive to cementum synthesis. In fact, if the $\mathrm{PP}_{\mathrm{i}}$ regulators ANK and NPP1 are developmentally modulated by cementoblasts to promote and then shut off acellular cementum formation, then such therapeutic modulation may be seen as an effort to locally recapitulate the developmental milieu. Practical considerations such as method of $\mathrm{PP}_{\mathrm{i}}$ modulation and delivery systems are being explored by our group and others [Osathanon et al., 2009].

\section{Acknowledgments}

The authors wish to thank Dr. Ceci Giachelli, Dr. Tracy Popowics, and Dr. Christopher Allan for questions and comments regarding the course of these studies. They would also like to thank Ms. Jirawan Wade for preparing histological sections. Special thanks go to Ms. Jan Berry for long-running input and editorial advice, and Dr. Francisco H. Nociti, Jr. and Dr. Erica Swanson for their roles in initiating this project. Thanks to the investigators who generously provided antibodies and probes: Dr. Larry Fisher, Dr. Marion Young, Dr. Renny Franceschi, Dr. Anne George, and Dr. Chunlin Qin. This work was supported by NIH/NIDCR RO1 DE15109 (M.J.S.) and NIH/NIAMS AR42236 (D.M.K.).

\section{References}

-Addison, W.N., F. Azari, E.S. Sorensen, M.T. Kaartinen, M.D. McKee (2007) Pyrophosphate inhibits mineralization of osteoblast cultures by binding to mineral, up-regulating osteopontin, and inhibiting alkaline phosphatase activity. J Biol Chem 282: 15872-15883.

Amir, L.R., A. Jovanovic, F.B. Perdijk, S. Toyosawa, V. Everts, A.L. Bronckers (2007) Immunolocalization of sibling and RUNX2 proteins during vertical distraction osteogenesis in the human mandible. J Histochem Cytochem 55: 1095-1104.
Baba, O., C. Qin, J.C. Brunn, J.N. Wygant, B.W. McIntyre, W.T. Butler (2004) Colocalization of dentin matrix protein 1 and dentin sialoprotein at late stages of rat molar development. Matrix Biol 23: 371-379.

Bashutski, J.D., H.L. Wang (2009) Periodontal and endodontic regeneration. J Endod 35: 321-328.

Beck, G.R., Jr. (2003) Inorganic phosphate as a signaling molecule in osteoblast differentiation. J Cell Biochem 90: 234-243.

Beck, G.R., Jr., B. Zerler, E. Moran (2000) Phosphate is a specific signal for induction of osteopontin gene expression. Proc Natl Acad Sci USA 97: 8352-8357.
Beertsen, W., C.A. McCulloch, J. Sodek (1997) The periodontal ligament: a unique, multifunctional connective tissue. Periodontology 2000 13: 20-40.

Beertsen, W., T. VandenBos, V. Everts (1999) Root development in mice lacking functional tissue non-specific alkaline phosphatase gene: inhibition of acellular cementum formation. J Dent Res 78: 1221-1229.

Berry, J.E., M. Zhao, Q. Jin, B.L. Foster, H. Viswanathan, M.J. Somerman (2003) Exploring the origins of cementoblasts and their trigger factors. Connect Tissue Res 44(suppl 1): 97-102. 
Bosshardt, D. (2005) Are cementoblasts a subpopulation of osteoblasts or a unique phenotype? J Dent Res 84: 390-406.

Bosshardt, D., H.E. Schroeder (1990) Evidence for rapid multipolar and slow unipolar production of human cellular and acellular cementum matrix with intrinsic fibers. J Clin Periodontol 17: 663-668.

Bosshardt, D.D., H.E. Schroeder (1996) Cementogenesis reviewed: a comparison between human premolars and rodent molars. Anat Rec 245: 267-292.

Bronckers, A.L., M.C. Farach-Carson, E. Van Waveren, W.T. Butler (1994) Immunolocalization of osteopontin, osteocalcin, and dentin sialoprotein during dental root formation and early cementogenesis in the rat. J Bone Miner Res 9: 833-841.

- Butler, W.T., J.C. Brunn, C. Qin, M.D. McKee (2002) Extracellular matrix proteins and the dynamics of dentin formation. Connect Tissue Res 43: 301-307.

Chen, I.P., C.J. Wang, S. Strecker, B. Koczon-Jaremko, A. Boskey, E.J. Reichenberger (2009) Introduction of a Phe377del mutation in ANK creates a mouse model for craniometaphyseal dysplasia. J Bone Miner Res 24: 1206-1215.

Chen, X.D., L.W. Fisher, P.G. Robey, M.F. Young (2004) The small leucine-rich proteoglycan biglycan modulates BMP-4-induced osteoblast differentiation. FASEB J 18: 948-958.

D'Errico, J.A., J.E. Berry, H. Ouyang, C.L. Strayhorn, J.J. Windle, M.J. Somerman (2000) Employing a transgenic animal model to obtain cementoblasts in vitro. J Periodontol 71: 63-72.

Diekwisch, T.G. (2001) The developmental biology of cementum. Int J Dev Biol 45: 695-706.

Fantner, G.E., J. Adams, P. Turner, P.J. Thurner, L.W. Fisher, P.K. Hansma (2007) Nanoscale ion mediated networks in bone: osteopontin can repeatedly dissipate large amounts of energy. Nano Lett 7: 2491-2498.

Fatherazi, S., D. Matsa-Dunn, B.L. Foster, R.B. Rutherford, M.J. Somerman, R.B. Presland (2009) Phosphate regulates osteopontin gene transcription. J Dent Res 88: 39-44.

Feng, J.Q., H. Huang, Y. Lu, L. Ye, Y. Xie, T.W. Tsutsui, T. Kunieda, T. Castranio, G. Scott, L.B. Bonewald, Y. Mishina (2003) The Dentin matrix protein 1 (Dmpl) is specifically expressed in mineralized, but not soft, tissues during development. J Dent Res 82: 776780 .

Fisher, L.W., N.S. Fedarko (2003) Six genes expressed in bones and teeth encode the current members of the SIBLING family of proteins. Connect Tissue Res 44(suppl 1): 33-40.

Fisher, L.W., J.T. Stubbs, 3rd, M.F. Young (1995) Antisera and cDNA probes to human and certain animal model bone matrix noncollagenous proteins. Acta Orthop Scand Suppl 266: 61-65.

Fleisch, H., S. Bisaz (1962) Mechanism of calcification: inhibitory role of pyrophosphate. $\mathrm{Na}$ ture 195: 911.
Fleischmannova, J., E. Matalova, P.T. Sharpe, I. Misek, R.J. Radlanski (2010) Formation of the tooth-bone interface. J Dent Res 89: 108-115.

Fong, H.K., B.L. Foster, M. Sarikaya, M.J. Somerman (2009) Ank/ank mutant mice roots as a model for periodontal tissue regeneration- a study of structure and mechanical properties. Arch Oral Biol, in press.

Foster, B.L., F.H. Nociti, Jr., E.C. Swanson, D. Matsa-Dunn, J.E. Berry, C.J. Cupp, P. Zhang, M.J. Somerman (2005) Regulation of SIBLING family genes by phosphate in cementoblasts: 8th International Conference on the Chemistry and Biology of Mineralized Tissues, Banff, Oct 2004.

Foster, B.L., F.H. Nociti, Jr., E.C. Swanson, D. Matsa-Dunn, J.E. Berry, C.J. Cupp, P. Zhang, M.J. Somerman (2006) Regulation of cementoblast gene expression by inorganic phosphate in vitro. Calcif Tissue Int 78: $103-$ 112.

Foster, B.L., T.E. Popowics, H.K. Fong, M.J. Somerman (2007) Advances in defining regulators of cementum development and periodontal regeneration. Curr Top Dev Biol 78: $47-126$.

Foster, B.L., K.A. Tompkins, R.B. Rutherford, H. Zhang, E.Y. Chu, H. Fong, M.J. Somerman (2008) Phosphate: known and potential roles during development and regeneration of teeth and supporting structures. Birth Defects Res C Embryo Today 84: 281-314.

Gajjeraman, S., K. Narayanan, J. Hao, C. Qin, A. George (2007) Matrix macromolecules in hard tissues control the nucleation and hierarchical assembly of hydroxyapatite. J Biol Chem 282: 1193-1204.

Gericke, A., C. Qin, L. Spevak, Y. Fujimoto, W.T. Butler, E.S. Sorensen, A.L. Boskey (2005) Importance of phosphorylation for osteopontin regulation of biomineralization. Calcif Tissue Int 77: 45-54.

Giachelli, C.M. (2005) Inducers and inhibitors of biomineralization: lessons from pathological calcification. Orthod Craniofac Res 8: 229-231.

Giannobile, W.V., M.J.Somerman (2003) Growth and amelogenin-like factors in periodontal wound healing. A systematic review. Ann Periodontol 8: 193-204.

Gluhak-Heinrich, J., L. Ye, L.F. Bonewald, J.Q. Feng, M. MacDougall, S.E. Harris, D. Pavlin (2003) Mechanical loading stimulates dentin matrix protein 1 (DMP1) expression in osteocytes in vivo. J Bone Miner Res 18: 807817.

Groeneveld, M.C., V. Everts, W. Beertsen (1995) Alkaline phosphatase activity in the periodontal ligament and gingiva of the rat molar: its relation to cementum formation. J Dent Res 74: 1374-1381.

Groeneveld, M.C., T. Van den Bos, V. Everts, W Beertsen (1996) Cell-bound and extracellular matrix-associated alkaline phosphatase activity in rat periodontal ligament. Experimental Oral Biology Group. J Periodontal Res 31: 73-79.
Gurley, K.A., H. Chen, C. Guenther, E.T. Nguyen, R.B. Rountree, M. Schoor, D.M. Kingsley (2006a) Mineral formation in joints caused by complete or joint-specific loss of ANK function. J Bone Miner Res 21: 1238-1247.

Gurley, K.A., R.J. Reimer, D.M. Kingsley (2006b) Biochemical and genetic analysis of ANK in arthritis and bone disease. Am J Hum Genet 79: 1017-1029.

Hao, J., B. Zou, K. Narayanan, A. George (2004) Differential expression patterns of the dentin matrix proteins during mineralized tissue formation. Bone 34: 921-932.

-Harmey, D., L. Hessle, S. Narisawa, K.A. Johnson, R. Terkeltaub, J.L. Millan (2004) Concerted regulation of inorganic pyrophosphate and osteopontin by akp2, enpp1, and ank: an integrated model of the pathogenesis of mineralization disorders. Am J Pathol 164: 1199-1209.

Harmey, D., K.A. Johnson, J. Zelken, N.P. Camacho, M.F. Hoylaerts, M. Noda, R. Terkeltaub, J.L. Millan (2006) Elevated skeletal osteopontin levels contribute to the hypophosphatasia phenotype in akp2(-/-) mice. J Bone Miner Res 21: 1377-1387.

Harris, N.L., K.R. Rattray, C.E. Tye, T.M. Underhill, M.J. Somerman, J.A. D'Errico, A.F Chambers, G.K. Hunter, H.A. Goldberg (2000) Functional analysis of bone sialoprotein: identification of the hydroxyapatitenucleating and cell-binding domains by recombinant peptide expression and site-directed mutagenesis. Bone 27: 795-802.

Heinonen, J.K. (2001) Biological Role of Inorganic Pyrophosphate. Norwell, Kluwer Academic Publishers.

Hessle, L., K.A. Johnson, H.C. Anderson, S. Narisawa, A. Sali, J.W. Goding, R. Terkeltaub, J.L. Millan (2002) Tissue-nonspecific alkaline phosphatase and plasma cell membrane glycoprotein-1 are central antagonistic regulators of bone mineralization. Proc Natl Acad Sci USA 99: 9445-9449.

Ho, A.M., M.D. Johnson, D.M. Kingsley (2000) Role of the mouse ank gene in control of tissue calcification and arthritis. Science 289: 265-270.

Hunter, G.K., H.A. Goldberg (1994) Modulation of crystal formation by bone phosphoproteins: role of glutamic acid-rich sequences in the nucleation of hydroxyapatite by bone sialoprotein. Biochem J 302: 175-179.

Hunter, G.K., C.L. Kyle, H.A. Goldberg (1994) Modulation of crystal formation by bone phosphoproteins: structural specificity of the osteopontin-mediated inhibition of hydroxyapatite formation. Biochem J 300: 723-728.

Johnson, K., J. Goding, D. Van Etten, A. Sali, S.I. Hu, D. Farley, H. Krug, L. Hessle, J.L. Millan, R. Terkeltaub (2003) Linked deficiencies in extracellular $\mathrm{PP}_{\mathrm{i}}$ and osteopontin mediate pathologic calcification associated with defective PC-1 and ANK expression. J Bone Miner Res 18: 994-1004. 
Johnson, K.A., L. Hessle, S. Vaingankar, C. Wennberg, S. Mauro, S. Narisawa, J.W. Goding, K. Sano, J.L. Millan, R. Terkeltaub (2000) Osteoblast tissue-nonspecific alkaline phosphatase antagonizes and regulates PC-1. Am J Physiol Regul Integr Comp Physiol 279: R1365-R1377.

Jowett, T., Y.-L. Yan (1996) Two-color wholemount in situ hybridization; in Krieg, P. (ed): A Laboratory Guide to RNA: Isolation, Analysis, and Synthesis. New York, Wiley, pp 381-409.

Kim, H.J., T. Minashima, E.F. McCarthy, J.A. Winkles, T. Kirsch (2010) Progressive ankylosis protein (ANK) in osteoblasts and osteoclasts controls bone formation and bone remodeling. J Bone Miner Res 25: 17711783.

Koshizuka, Y., S. Ikegawa, M. Sano, K. Nakamura, Y. Nakamura (2001) Isolation of novel mouse genes associated with ectopic ossification by differential display method using ttw, a mouse model for ectopic ossification. Cytogenet Cell Genet 94: 163-168.

Lian, J.B., G.S. Stein (1992) Concepts of osteoblast growth and differentiation: basis for modulation of bone cell development and tissue formation. Crit Rev Oral Biol Med 3: 269-305.

Lillie, R.D. (1965) Histopathological Technique and Practical Histochemistry. New York, McGraw Hill Book Company.

Lomashvili, K.A., P. Garg, S. Narisawa, J.L. Millan, W.C. O’Neill (2008) Upregulation of alkaline phosphatase and pyrophosphate hydrolysis: potential mechanism for uremic vascular calcification. Kidney Int 73: 10241030.

Luan, X., Y. Ito, S. Holliday, C. Walker, J. Daniel, T. Galang, T. Fukui, A. Yamane, E. Begole, C. Evans, T. Diekwisch (2007) Extracellular matrix-mediated tissue remodeling following axial movement of teeth. J Histochem Cytochem 55: 127-140.

MacDougall, M., T.T. Gu, X. Luan, D. Simmons, J. Chen (1998) Identification of a novel isoform of mouse dentin matrix protein 1: spatial expression in mineralized tissues. J Bone Miner Res 13: 422-431.

Maciejewska, I., C. Cowan, K. Svoboda, W.T. Butler, R. D’Souza, C. Qin (2009) The NH2terminal and $\mathrm{COOH}$-terminal fragments of dentin matrix protein 1 (DMP1) localize differently in the compartments of dentin and growth plate of bone. J Histochem Cytochem 57: 155-166.

MacNeil, R.L., J. Berry, J. D’Errico, C. Strayhorn, B. Piotrowski, M.J. Somerman (1995) Role of two mineral-associated adhesion molecules, osteopontin and bone sialoprotein, during cementogenesis. Connect Tissue Res 33: 1-7.

Malkin, I., S. Dahm, A. Suk, E. Kobyliansky, M. Toliat, N. Ruf, G. Livshits, P. Nurnberg (2005) Association of ANKH gene polymorphisms with radiographic hand bone size and geometry in a Chuvasha population. Bone 36: 365-373.
McCulloch, C., P. Lekic, M. McKee (2000) Role of physical forces in regulating the form and function of the periodontal ligament. Periodontology 2000 24: 56-72.

McKee, M.D., S. Zalzal, A. Nanci (1996) Extracellular matrix in tooth cementum and mantle dentin: localization of osteopontin and other noncollagenous proteins, plasma proteins, and glycoconjugates by electron microscopy. Anat Rec 245: 293-312.

Meyer, J.L. (1984) Can biological calcification occur in the presence of pyrophosphate? Arch Biochem Biophys 231: 1-8.

Millan, J.L. (2006) Mammalian Alkaline Phosphatases. Weinheim, Wiley-VCH Verlag.

Morava, E., J. Kühnisch, J. Drijvers, J. Robben, C. Cremers, P. van Setten, A. Branten, S. Stumpp, A. de Jong, K. Voesenek, S. Vermeer, A. Heister, H. Claahsen-van der Grinten, C. O’Neill, M. Willemsen, D. Lefeber, P. Deen, U. Kornak, H. Kremer, R. Wevers (2010) Autosomal recessive mental retardation, deafness, ankylosis, and mild hypophosphatemia associated with a novel ANKH mutation in a consanguineous family. J Clin Endocrinol Metab. Oct 13, Epub ahead of print.

Morotome, Y., M. Goseki-Sone, I. Ishikawa, S. Oida (1998) Gene expression of growth and differentiation factors-5, -6 , and -7 in developing bovine tooth at the root forming stage. Biochem Biophys Res Commun 244: 85-90.

Murshed, M., D. Harmey, J.L. Millan, M.D. McKee, G. Karsenty (2005) Unique coexpression in osteoblasts of broadly expressed genes accounts for the spatial restriction of ECM mineralization to bone. Genes Dev 19: 1093-1104.

Narisawa, S., N. Frohlander, J.L. Millan (1997) Inactivation of two mouse alkaline phosphatase genes and establishment of a model of infantile hypophosphatasia. Dev Dyn 208: 432-446.

Netter, P., T. Bardin, A. Bianchi, P. Richette, D. Loeuille (2004) The ANKH gene and familial calcium pyrophosphate dihydrate deposition disease. Joint Bone Spine 71: 365-368.

Nociti, F.H., Jr., J.E. Berry, B.L. Foster, K.A. Gurley, D.M. Kingsley, T. Takata, M. Miyauchi, M.J. Somerman (2002) Cementum: a phosphate-sensitive tissue. J Dent Res 81: 817821.

Nurnberg, P., H. Thiele, D. Chandler, W. Hohne, M.L. Cunningham, H. Ritter, G. Leschik, K. Uhlmann, C. Mischung, K. Harrop, J. Goldblatt, Z.U. Borochowitz, D. Kotzot, F. Westermann, S. Mundlos, H.S. Braun, N. Laing, S. Tinschert (2001) Heterozygous mutations in $\mathrm{ANKH}$, the human ortholog of the mouse progressive ankylosis gene, result in craniometaphyseal dysplasia. Nat Genet 28: 37-41.

Ogbureke, K.U., L.W. Fisher (2004) Expression of SIBLINGs and their partner MMPs in salivary glands. J Dent Res 83: 664-670.
Ogbureke, K.U., L.W. Fisher (2007) SIBLING expression patterns in duct epithelia reflect the degree of metabolic activity. J Histochem Cytochem 55: 403-409.

Osathanon, T., C.M. Giachelli, M.J. Somerman (2009) Immobilization of alkaline phosphatase on microporous nanofibrous fibrin scaffolds for bone tissue engineering. Biomaterials 30: 4513-4521.

Owen, T.A., M. Aronow, V. Shalhoub, L.M. Barone, L. Wilming, M.S. Tassinari, M.B. Kennedy, S. Pockwinse, J.B. Lian, G.S. Stein (1990) Progressive development of the rat osteoblast phenotype in vitro: reciprocal relationships in expression of genes associated with osteoblast proliferation and differentiation during formation of the bone extracellular matrix. J Cell Physiol 143: 420-430.

Parichy, D.M., D.G. Ransom, B. Paw, L.I. Zon, S.L. Johnson (2000) An orthologue of the kitrelated gene fms is required for development of neural crest-derived xanthophores and a subpopulation of adult melanocytes in the zebrafish, Danio rerio. Development 127: 3031-3044.

-Pavlin, D., J. Gluhak-Heinrich (2001) Effect of mechanical loading on periodontal cells. Crit Rev Oral Biol Med 12: 414-424.

Pendleton, A., M.D. Johnson, A. Hughes, K.A. Gurley, A.M. Ho, M. Doherty, J. Dixey, P. Gillet, D. Loeuille, R. McGrath, A. Reginato, R. Shiang, G. Wright, P. Netter, C. Williams, D.M. Kingsley (2002) Mutations in ANKH cause chondrocalcinosis. Am J Hum Genet 71: 933-940.

Qin, C., O. Baba, W.T. Butler (2004) Post-translational modifications of sibling proteins and their roles in osteogenesis and dentinogenesis. Crit Rev Oral Biol Med 15: 126-136.

Qin, C., R. D’Souza, J.Q. Feng (2007) Dentin matrix protein 1 (DMP1): new and important roles for biomineralization and phosphate homeostasis. J Dent Res 86: 1134-1141.

Reichenberger, E., V. Tiziani, S. Watanabe, L. Park, Y. Ueki, C. Santanna, S.T. Baur, R. Shiang, D.K. Grange, P. Beighton, J. Gardner, H. Hamersma, S. Sellars, R. Ramesar, A.C. Lidral, A. Sommer, C.M. Raposo do Amaral, R.J. Gorlin, J.B. Mulliken, B.R. Olsen (2001) Autosomal dominant craniometaphyseal dysplasia is caused by mutations in the transmembrane protein ANK. Am J Hum Genet 68: 1321-1326.

Rutherford, R.B., B.L. Foster, T. Bammler, R.P. Beyer, S. Sato, M.J. Somerman (2006) Extracellular phosphate alters cementoblast gene expression. J Dent Res 85: 505-509.

Ryan, L.M. (2001) The ank gene story. Arthritis Res 3: 77-79.

Schaefer, L., H. Hausser, M. Altenburger, J. Ugorcakova, C. August, L.W. Fisher, R.M. Schaefer, H. Kresse (1998) Decorin, biglycan and their endocytosis receptor in rat renal cortex. Kidney Int 54: 1529-1541. 
Sena, K., Y. Morotome, O. Baba, T. Terashima, Y. Takano, I. Ishikawa (2003) Gene expression of growth differentiation factors in the developing periodontium of rat molars. J Dent Res 82: 166-171.

Shimono, M., T. Ishikawa, H. Ishikawa, H. Matsuzaki, S. Hashimoto, T. Muramatsu, K. Shima, K. Matsuzaka, T. Inoue (2003) Regulatory mechanisms of periodontal regeneration. Microsc Res Tech 60: 491-502.

- Terkeltaub, R.A. (2001) Inorganic pyrophosphate generation and disposition in pathophysiology. Am J Physiol Cell Physiol 281: C1-C11.

- Toyosawa, S., S. Shintani, T. Fujiwara, T. Ooshima, A. Sato, N. Ijuhin, T. Komori (2001) Dentin matrix protein 1 is predominantly expressed in chicken and rat osteocytes but not in osteoblasts. J Bone Miner Res 16: 20172026.

van den Bos, T., G. Handoko, A. Niehof, L.M. Ryan, S.P. Coburn, M.P. Whyte, W. Beertsen (2005) Cementum and dentin in hypophosphatasia. J Dent Res 84: 1021-1025.
VandenBos, T., A.L. Bronckers, H.A. Goldberg, W. Beertsen (1999) Blood circulation as source for osteopontin in acellular extrinsic fiber cementum and other mineralizing tissues. J Dent Res 78: 1688-1695.

Wang, D., K. Christensen, K. Chawla, G. Xiao, P.H. Krebsbach, R.T. Franceschi (1999) Isolation and characterization of MC3T3-E1 preosteoblast subclones with distinct in vitro and in vivo differentiation/mineralization potential. J Bone Miner Res 14: 893-903.

Whyte, M.P. (1994) Hypophosphatasia and the role of alkaline phosphatase in skeletal mineralization. Endocr Rev 15: 439-461.

Whyte, M.P. (2002) Hypophosphatasia Nature's window to alkaline phosphatase in man; in Bilezikian, J.P., L.G. Raisz, G.A. Rodan (eds): Principles of Bone Biology. San Diego, Academic Press, pp 1229-1248.

-Wise, G.E., G.J. King (2008) Mechanisms of tooth eruption and orthodontic tooth movement. J Dent Res 87: 414-434.
Yang, W., I. Kalajzic, Y. Lu, D. Guo, M.A. Harris, J. Gluhak-Heinrich, L.F. Bonewald, J.Q. Feng, D.W. Rowe, S.E. Harris (2004) In vitro and in vivo study on osteocyte-specific mechanical signaling pathways. J Musculoskelet Neuronal Interact 4: 386-387.

Yang, W., Y. Lu, I. Kalajzic, D. Guo, M.A. Harris, J. Gluhak-Heinrich, S. Kotha, L.F. Bonewald, J.Q. Feng, D.W. Rowe, C.H. Turner, A.G. Robling, S.E. Harris (2005) Dentin matrix protein 1 gene cis-regulation: use in osteocytes to characterize local responses to mechanical loading in vitro and in vivo. J Biol Chem 280: 20680-20690.

Ye, L., S. Zhang, H. Ke, L.F. Bonewald, J. Feng (2008) Periodontal breakdown in the dmpl null mouse model of hypophosphatemic rickets. J Dent Res 87: 624-629.

Zhang, H., M.J. Somerman, J. Berg, M.L. Cunningham, B. Williams (2007) Dental anomalies in a child with craniometaphysial dysplasia. Pediatr Dent 29: 415-419. 